\title{
Late Miocene to Pleistocene sequences at the New Jersey outer continental shelf (ODP leg 174A, sites 1071 and 1072)
}

\author{
J.M. Metzger ${ }^{\mathrm{a}, 1}$, P.B. Flemings ${ }^{\mathrm{a}, *}$, N. Christie-Blick ${ }^{\mathrm{b}, \mathrm{c}, 2}$, G.S. Mountain ${ }^{\mathrm{c}, 3}$, \\ J.A. Austin Jr. ${ }^{\mathrm{d}, 4}$, S.P. Hesselbo ${ }^{\mathrm{e}, 5}$ \\ ${ }^{a}$ Department of Geosciences, Pennsylvania State University, University Park, PA 16802, USA \\ ${ }^{\mathrm{b}}$ Department of Earth and Environmental Sciences, Columbia University Columbia, NY, USA \\ ${ }^{\mathrm{c}}$ Lamont-Doherty Earth Observatory of Columbia University, Palisades, NY 10964, USA \\ ${ }^{\mathrm{d}}$ University of Texas Institute for Geophysics, Austin, TX 78759, USA \\ ${ }^{\mathrm{e}}$ Department of Earth Sciences, University of Oxford, Oxford OX1 3PR, UK
}

\begin{abstract}
2-D seismic, wireline log, and core data at ODP Leg 174A Sites 1071 and 1072 on the outer continental shelf of New Jersey reveal two major depositional sequences of late Miocene-Pliocene and Pleistocene age. The late Miocene-Pliocene sequence is a thick $(\sim 100 \mathrm{~m})$ deepening-upward succession landward of the clinoform rollover and a shoaling-upward succession seaward of the clinoform rollover. The Pleistocene sequence deepens abruptly near its base, shoals upward, and then deepens again before it is truncated by its overlying unconformity. There is no onlap onto clinoforms (no lowstand wedge) in either sequence. Sequence stratigraphic analysis and a geometric depositional model are used to interpret that the unusually thick transgressive component of the late Miocene-Pliocene sequence was formed by high-frequency eustatic cycles (1-2 m.y.) superimposed on a longer-term eustatic rise ( $\sim 5$ m.y.). This conclusion is supported by independent evidence of eustasy. The sequences of this study are correlated to sequences in the North Atlantic coastal plain and in the Great Bahama Bank. These sequences have very different architectures than underlying middle Miocene sequences, which contain thick lowstand wedge deposits, and are interpreted to have formed by high-frequency eustatic cycles superimposed on longer-term eustatic fall. (c) 2000 Elsevier Science B.V. All rights reserved.
\end{abstract}

Keywords: sequence; stratigraphy; New Jersey; Neogene; seismic

\footnotetext{
* Corresponding author. Fax: +1-814-863-7823.

E-mail addresses: john_metzger@anadarko.com (J.M. Metzger), flemings@geosc.psu.edu (P.B. Flemings), ncb@ldeo. columbia.edu (N. Christie-Blick), mountain@1deo.columbia.edu (G.S. Mountain), jamie@utig.ig.utexas.edu (J.A. Austin Jr.), stephen.hesselbo@earth.ox.ac.uk (S.P. Hesselbo).

${ }^{1}$ Present address: Anadarko Petroleum Corporation, 17001 Northchase Dr, Houston, TX 77060.

${ }^{2}$ Fax: +1-914-365-8150.

${ }^{3}$ Fax: +1-914-365-8168.

${ }^{4}$ Fax: + 1-512-471-0450.

${ }^{5}$ Fax: +44-1865-272072.
}

\section{Introduction}

The New Jersey continental margin is an ideal place to examine the influence of Cenozoic eustatic change on sequence architecture (Greenlee and Moore, 1988; Christie-Blick et al., 1990; Greenlee et al., 1992; Miller et al., 1998a) because it is a mature passive margin with no major Neogene faulting, has undergone minimal recent tectonic deformation, and has low, well-defined, thermal subsidence rates (<10 m/m.y.; Steckler and Watts, 1982; Poag, 1985; Grow and Sheridan, 1988; Poag and Sevon, 1989). 
The New Jersey slope was drilled during Deep Sea Drilling Project (DSDP) Legs 93 and 95 (van Hinte and Wise, 1987; Poag and Watts, 1987), and Ocean Drilling Program (ODP) Leg 150 (Mountain et al., 1996). During ODP Leg 150X (Miller and Snyder, 1997) and ODP Leg 174AX (Miller et al., 1998b), onshore stata of the New Jersey coastal plain were drilled. From these data, Miller et al. (1998a) inferred that glacioeustacy was the primary control on sequence formation in this region since the middle Eocene, based on synchroneity of slope and coastal plain sequence boundaries and their correlation with rapid ice volume increases inferred from the marine oxygen isotope record.

Previous seismic studies on the New Jersey continental shelf utilized industry boreholes and variably spaced $(3-20 \mathrm{~km})$ 2-D seismic data. Greenlee et al. (1988) and Greenlee and Moore (1988) identified second- and third-order Cenozoic sequences that correlate with the timing of boundaries interpreted by Haq et al. (1987). Greenlee et al. (1992) identified lowstand and highstand systems tracts within Miocene strata. Fulthorpe and Austin (1998) showed that middle Miocene sequences lack significant canyons at clinoform rollovers. Poulsen et al. (1998) interpreted a three-dimensional complexity in middle Miocene sequence architecture and suggested that sequence architecture was strongly affected by local sediment accumulation patterns. Fulthorpe et al. (1999) used seismic data to identify small fluvial channels landward of clinoform rollovers in middle and upper Miocene sequences.

In 1997, the New Jersey shelf and slope were drilled during ODP Leg 174A (Austin et al., 1998). ODP Sites 1071 and 1072 were drilled on the outer continental shelf and ODP Site 1073 was drilled on the modern slope (Fig. 1). The ODP Leg 174A shipboard scientific party identified two depositional sequences that contain thick $(\sim 100 \mathrm{~m})$, deepeningupward, successions on the paleo-shelf in the region between ODP Sites 1071 and 1072. This study builds on the foundation established by the shipboard scientific party of ODP Leg 174A (Austin et al., 1998). We augment the shipboard efforts by: (1) mapping seismic profiles both downdip and updip of ODP Sites 1071 and 1072 and incorporating industry borehole data at a location $\sim 10 \mathrm{~km}$ seaward of ODP Site 1072; (2) identifying distinct seismic-scale deposi- tional "units" by using an integrated analysis of seismic, wireline log, and core data within the upper Miocene to Pleistocene succession; (3) interpreting the depositional and erosional processes that led to the formation of these sequences; (4) comparing the internal stacking patterns with existing sequence stratigraphic models and previous work in the region; (5) relating stratal successions to the published record of eustatic change; and (6) correlating our depositional sequences with previous work on the North Atlantic coastal plain and on the Great Bahama Bank.

\section{Data}

A 2-D seismic survey was conducted in July 1995 during cruise number 270 of the R/V Oceanus $(O c 270)$ in preparation for ODP Leg 174A. The Oc 270 data are high frequency $(\sim 80 \mathrm{~Hz}$ in the shallow section) and have a vertical resolution of $\sim 5 \mathrm{~m}$. There are seven northwest trending dip profiles and 13 northeast trending strike profiles surrounding ODP Sites 1071 and 1072 (Fig. 1). Updip of these seismic hazard profiles are three regional dip profiles: 145, 247, and 149 (Fig. 1).

Five boreholes were drilled at ODP Site 1071 (Holes A-E) but wireline logs were not run owing to borehole instability. Continuous coring was attempted at Hole 1071C to a depth of 257.4 meters below the sea floor (mbsf) and the average recovery was $33.9 \%$ (Fig. 6). Two boreholes, Holes $1071 \mathrm{~F}$ and 1071G, were drilled $1 \mathrm{~km}$ east of Hole 1071C (Fig. 1). At Hole 1071G, Logging-While-Drilling (LWD) was accomplished to $95.1 \mathrm{mbsf}$. Continuous coring was attempted at Hole 1071F between $252-424.2 \mathrm{mbsf}$ with $13.5 \%$ core recovery. The Continental Offshore Stratigraphic Test (COST B2) borehole (Smith et al., 1976; Scholle, 1977) was drilled in 1976. This borehole is located $950 \mathrm{~m}$ south-southwest of Holes $1071 \mathrm{~A}-\mathrm{E}$ and is used in conjunction with the ODP Site 1071 core data to interpret intervals where no core was recovered.

ODP Site 1072 is located $3.5 \mathrm{~km}$ seaward of ODP Site 1071 Holes A-E and is composed of four boreholes spaced within $50 \mathrm{~m}$ of each other (Fig. 1B). Hole 1072A was cored to $306.8 \mathrm{mbsf}$ with an average recovery of $49.5 \%$. Holes 1072A, 1072B, and 1072C were wireline logged to depths of $300 \mathrm{mbsf}$, 
$307 \mathrm{mbsf}$, and $106 \mathrm{mbsf}$, respectively. At Hole 1072D, LWD was accomplished to 356 mbsf. A checkshot survey was undertaken at Hole 1072B. The Exxon 684-1 borehole, drilled in 1978, is located $\sim 10 \mathrm{~km}$ seaward of ODP Site 1072 (Fig. 8).

\section{Methods}

Prominent seismic reflections were mapped from the hazard surveys and extended landward (Figs. 1-5) and seaward (Fig. 8). To link lithologic and seismic data, a time-depth calibration was constructed at ODP Sites 1071, 1072, and at the 684-1 borehole. A synthetic seismogram was created using the Hole 1072A log data to gain insights into how different lithofacies were seismically imaged. Seismic reflections were tied to core and wireline log data on the basis of the time-depth calibration at each borehole. Depositional units were identified on the basis of distinct characteristics of seismic facies, wireline log response, and cored sediments. Wireline logs were used to interpret the lithology in coring gaps, especially in intervals of low recovery where the recovered core may not be representative of the lithology of a unit.

\section{Characterization and interpretation of the late Miocene-Pliocene and Pleistocene sequences}

We mapped two successive depositional sequences: the late Miocene-Pliocene sequence and the Pleistocene sequence. The late Miocene-Pliocene sequence is bounded below by the $\mathrm{m} 0.5(\mathrm{~s})$ sequence boundary, above by the pp4(s) sequence boundary, and contains a prominent flooding surface, the late Miocene flooding surface (Figs. 2, 3 and 8). The overlying Pleistocene sequence is bounded below by the $\mathrm{pp} 4(\mathrm{~s})$ sequence boundary, above by the pp3(s) sequence boundary, and contains the Pleistocene flooding surface (Figs. 2, 3 and 8).

\subsection{Sequence boundaries}

\subsubsection{The m0.5(s) sequence boundary}

The $\mathrm{m} 0.5(\mathrm{~s})$ clinoform rollover is located $\sim 1 \mathrm{~km}$ seaward of ODP Site 1072 on Oc270 line 51 (Fig. 8). Reflections terminate updip against the $\mathrm{m} 0.5(\mathrm{~s})$ sequence boundary (Figs. 2 and 3). Just above $\mathrm{m} 0.5(\mathrm{~s})$, core at Hole 1071F $(\sim 2.5 \mathrm{~km}$ landward of the clinoform rollover) consists of dark grey siltyclay, pebbly-muddy-sand, thinly laminated zones of black clay with abundant pollen and fungal spores (Core 174A-1071F-1R-2R) (Fig. 3); these are interpreted as lagoonal/estuarine deposits (Austin et al., 1998). Marginal marine and lagoonal/estuarine sedimentation immediately above m0.5(s) suggests that water depths were shallow during $\mathrm{m} 0.5(\mathrm{~s})$ formation and perhaps the $\mathrm{m} 0.5(\mathrm{~s})$ clinoform rollover was subaerially exposed (Figs. 2, 3 and 8). Biostratigraphy constrains m0.5(s) to greater than 8.6 Ma (Table 1). We interpret $\mathrm{m} 0.5(\mathrm{~s})$ as an erosional unconformity that was formed during subaerial exposure of the paleo-shelf and modified by erosion due to shoreface retreat during transgression (Nummedal and Swift, 1987; Walker and Eyles, 1991; Posamentier and Allen, 1993; Walker, 1995).

\subsubsection{The $p p 4(s)$ sequence boundary}

The $\mathrm{pp} 4$ (s) clinoform rollover is $10 \mathrm{~km}$ seaward of ODP Site 1072 on Oc270 line 51 where it is penetrated by the 684-1 borehole (Fig. 8). The pp4(s) sequence boundary separates low-amplitude offlapping reflections below from high-amplitude, sub-horizontal reflections above (Fig. 8). On seismic data, there is no obvious evidence of channel incision. However, there is $5 \mathrm{~m}$ of erosional relief present in multiple penetrations of the pp4(s) surface at ODP Site 1072 (Fig. 7). Overlying $\mathrm{pp} 4(\mathrm{~s})$, a shelly glauconitic fine-grained sand was recovered at Hole 1071C (Core 174A-1071C-10X) (Fig. 6). At ODP Site 1072 sediments above pp4(s) consist of dark green, poorly sorted, fine to coarse pebbly glauconite sand (Core 174A-1072A-27R) (Fig. 7). Wireline logs at the COST B2 borehole near the ODP Site 1071 and at ODP Site 1072 record these glauconitic sediments above the pp4(s) surface with high gamma ray values (Figs. 6 and 7). Biostratigraphy constrains strata underlying pp4(s) to as young as $1.7 \mathrm{Ma}$ while strata overlying pp4(s) are as old as $1.4 \mathrm{Ma}$ (Table 1). The pp4(s) surface is interpreted as an erosional unconformity that formed during regression and was modified by erosion due to shoreface retreat during transgression. 
A.

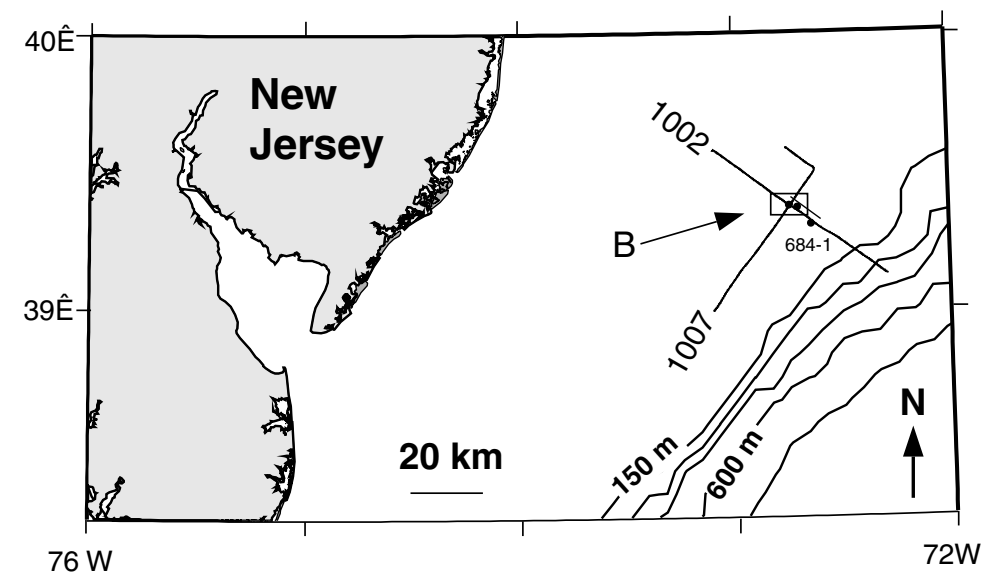

B.

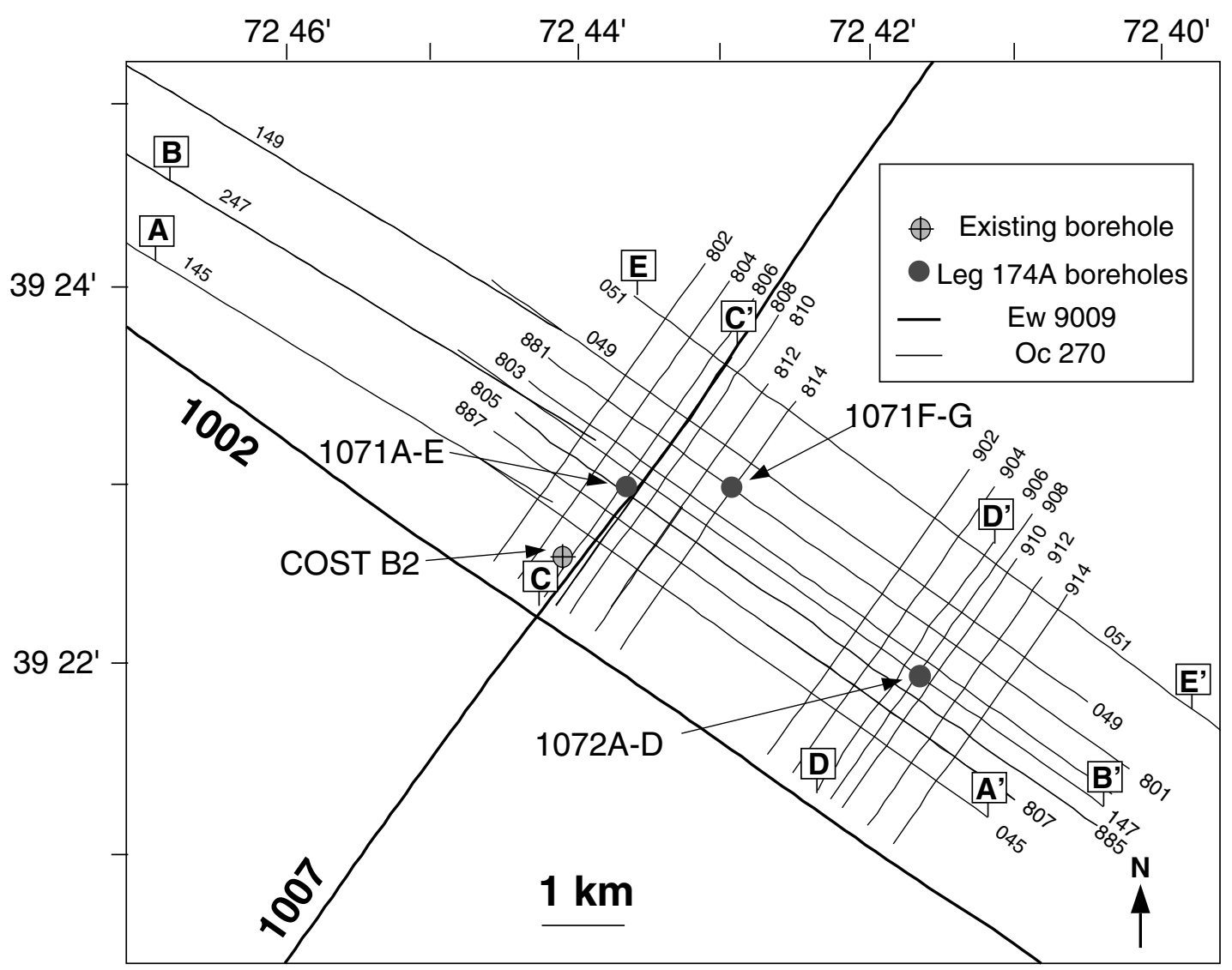

Fig. 1. (A) Multichannel seismic data examined in this study comprise a $10 \mathrm{~km}^{2}$ grid within the small rectangle. Study area lies on the outer continental shelf of New Jersey, inboard of the $150 \mathrm{~m}$ bathymetric contour. Ewing seismic profiles 1002 and 1007 were interpreted by Poulsen et al. (1998). (B) Expanded view of the study region. The seismic grids surrounding ODP Sites 1071 and 1072 were shot at $150-300 \mathrm{~m}$ spacing for shallow hazard assessment of potential sites. 

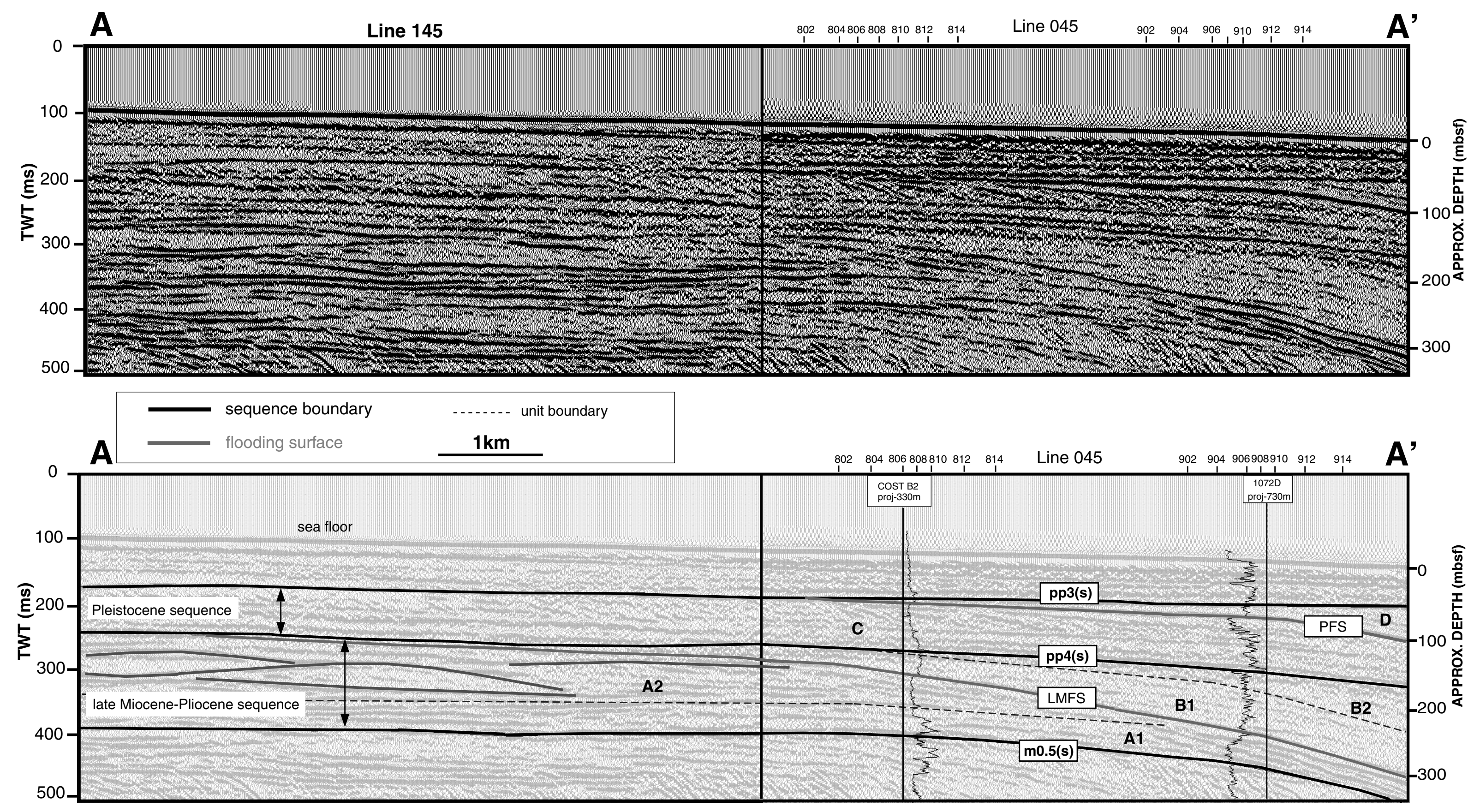
Fig. 2. Dip-oriented Oceanus seismic profile A-A' (located in Fig. 1). Top: uninterpreted; Bottom: interpreted. Nearby borehole gamma ray
logs are projected onto the seismic profile. Sequence boundaries (m0.5(s), pp4(s), and pp3(s)), the late Miocene flooding surface (LMFS), the Pleistocene flooding surface (PFS), and depositional units ( $\mathrm{A}_{1}, \mathrm{~A}_{2}, \mathrm{~B}_{1}, \mathrm{~B}_{2}, \mathrm{C}$ and $\left.\mathrm{D}\right)$ are described in the text. Depth estimates (right-hand side) are based on the ODP Site 1072 checkshot survey. This applies to all figures with seismic profiles. TWT - two-way traveltime; mbsf-meters below the sea floor. 

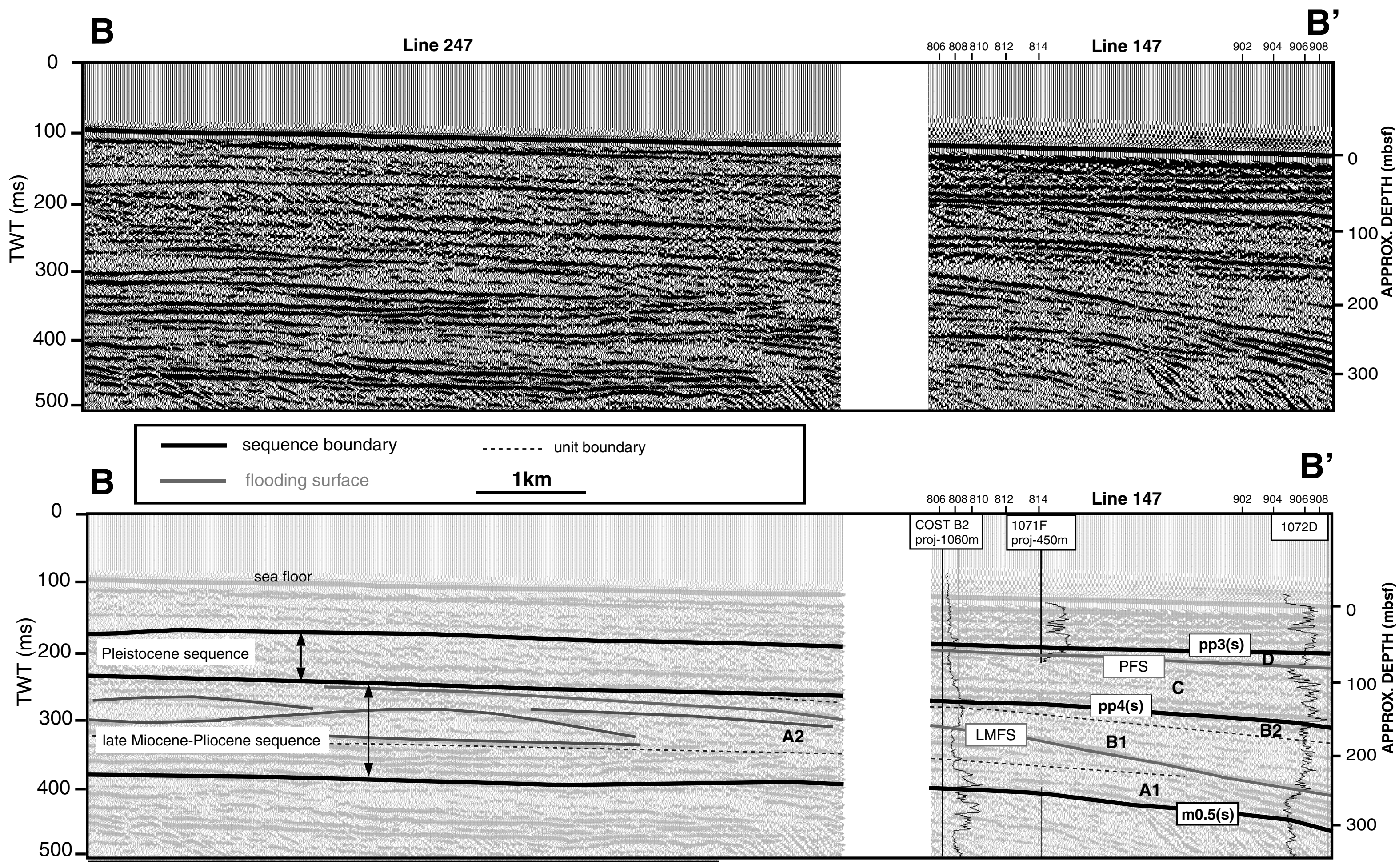

Fig. 3. Dip-oriented Oceanus seismic profile B-B' (located in Fig. 1). Top: uninterpreted; Bottom: interpreted. Nearby borehole gamma ray logs

are projected onto the seismic profile. TWT - two-way traveltime; mbsf - meters below the sea floor. 

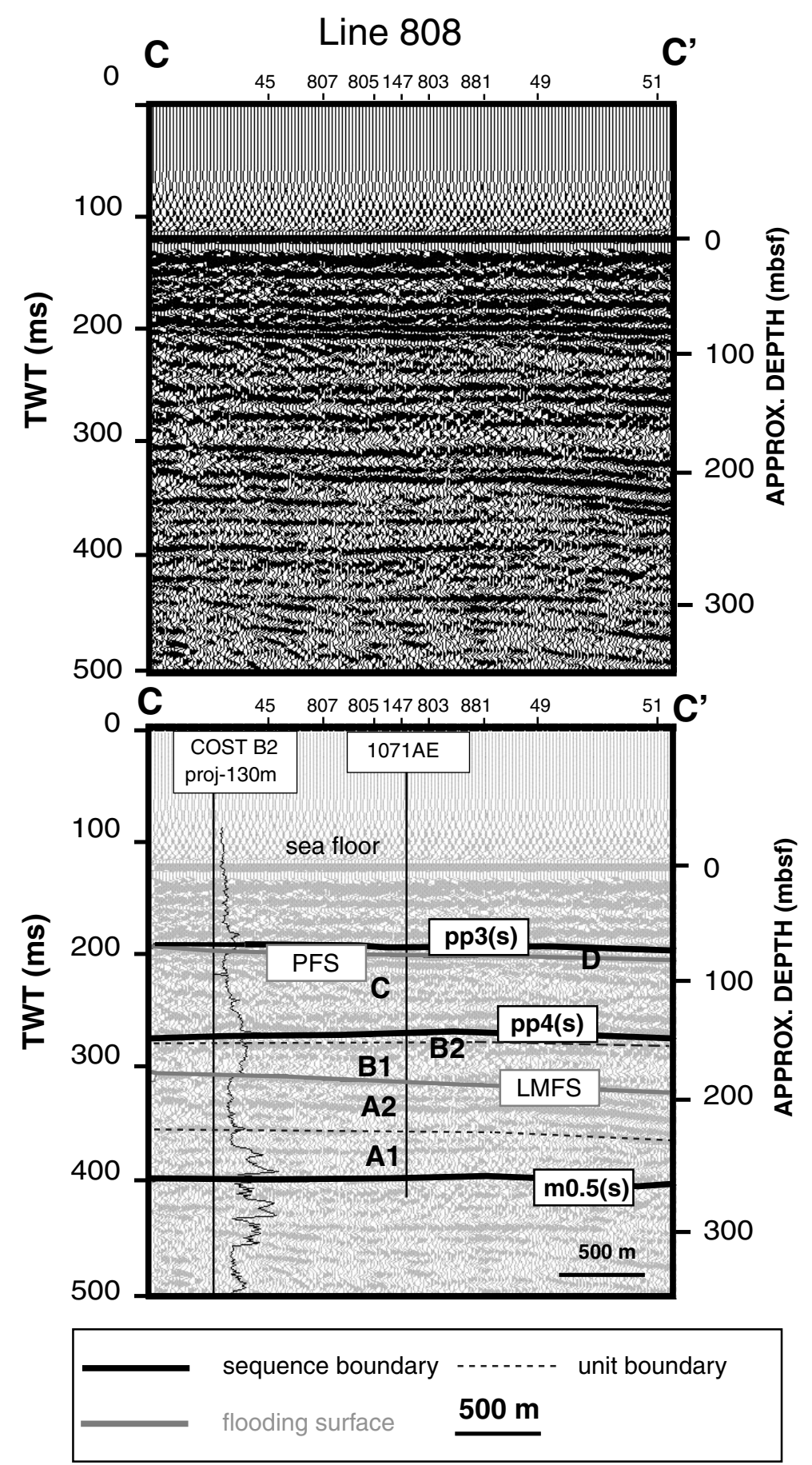

Fig. 4. Strike-oriented Oceanus seismic profile C-C' (located in Fig. 1). Top: uninterpreted; Bottom: interpreted. The COST B2 gamma ray log is projected onto the seismic profile. No logs were run at Holes $1071 \mathrm{~A}-\mathrm{E}$, but these holes are located on this line (Fig. $1 \mathrm{~b}$ ). Unit $\mathrm{B}_{2}$ and $\mathrm{D}$ are both very thin in this updip (landward) location. TWT - two-way traveltime; mbsf-meters below the sea floor. 


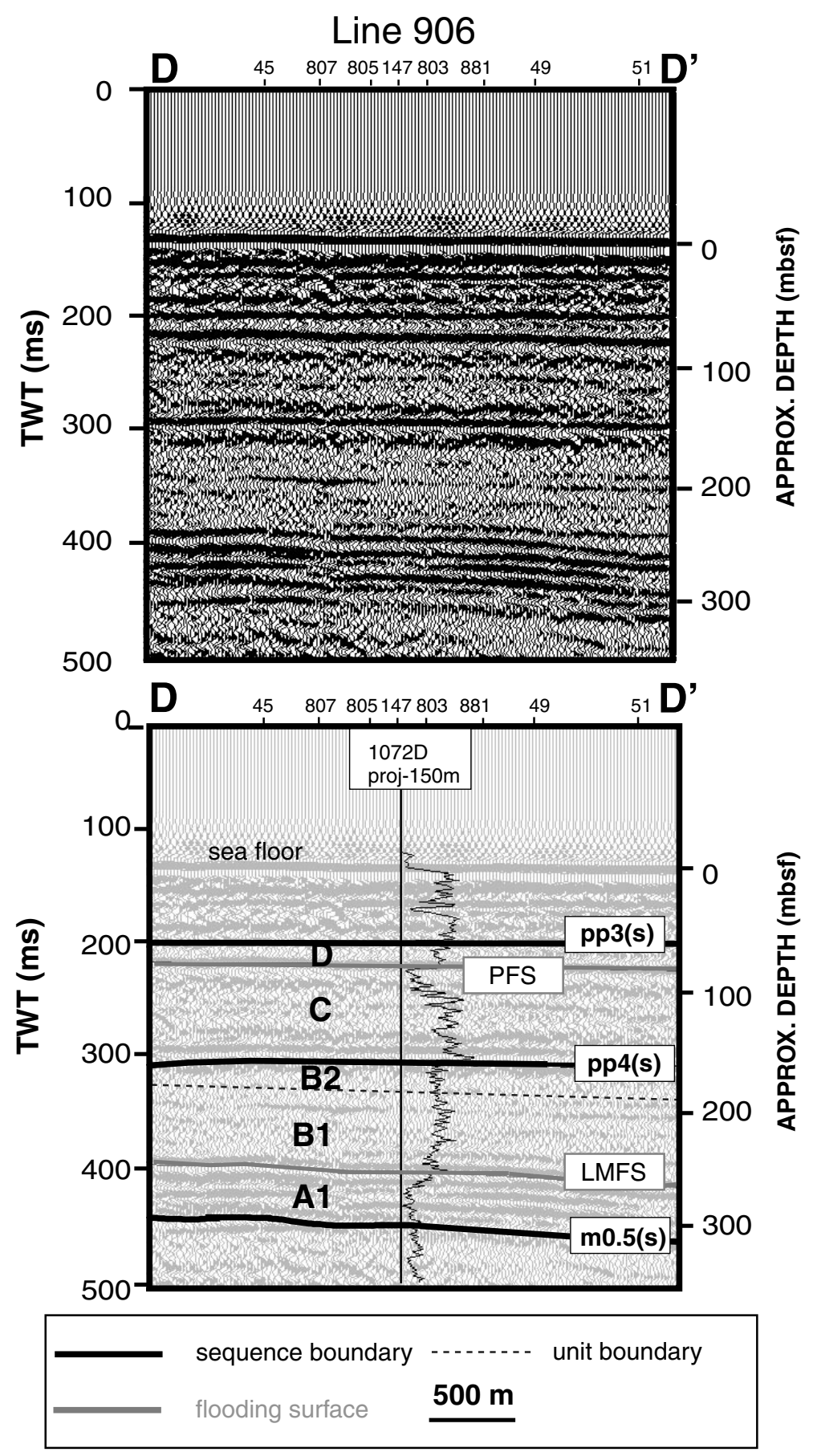

Fig. 5. Strike-parallel Oceanus seismic profile D-D' (located in Fig. 1). Top: uninterpreted; Bottom: interpreted. Hole 1072D LWD (loggingwhile-drilling) gamma ray $\log$ is projected onto the seismic profile. Low-amplitude character of unit $\mathrm{B}_{1}$ reflects homogeneous mud-prone nature. TWT - two-way traveltime; mbsf - meters below the sea floor. 
Table 1

Seismic surface ages. This table summarizes ODP Leg 174A Initial Reports age constraints for sequence boundaries m0.5(s), pp4(s), pp3(s), the late Miocene flooding surface (LMFS) and the Pleistocene flooding surface (PFS). The late Miocene flooding surface is termed pp5(s) in the ODP Leg 174A Initial Reports (Austin et al., 1998). The Pleistocene flooding surface is not identified in previous work. Depths to surfaces are derived from checkshot survey time-ties (Figs. 6 and 7). The age ranges of surfaces are constrained by microfossil assemblages above and below each surface. Surfaces pp3(s) and pp4(s) were tied to ODP Site 1073 on the continental slope to better constrain their ages. Nannos= nannofossils; dinos = dinocysts; paleomag = paleomagnetics; $\mathrm{mbsf}=$ meters below sea floor; PFS $=$ Pleistocene flooding surface; LMFS $=$ late Miocene flooding surface

\begin{tabular}{|c|c|c|c|c|}
\hline Surface & & Hole $1071 \mathrm{C}$ age constraints & Hole $1072 \mathrm{~A}$ age constraints & Site 1073 age constraints \\
\hline \multirow[t]{3}{*}{$\mathrm{pp} 3(\mathrm{~s})$} & Above & 0.78 (paleomag) $61.4 \mathrm{mbsf}$ & $\begin{array}{l}0.25-0.78 \mathrm{Ma} \text { (nannos, } \\
\text { paleomag) } 57.79 \mathrm{mbsf}\end{array}$ & $\begin{array}{l}0.25 \mathrm{Ma} \text { (nannos) } \\
102.36 / 109.82 \mathrm{mbsf}\end{array}$ \\
\hline & Depth & $62 \mathrm{mbsf}$ & $58 \mathrm{mbsf}$ & $\begin{array}{l}\text { At or above } 324.86 \text { mbsf (ODP } \\
174 \text { A Core-1073-36X) }\end{array}$ \\
\hline & Below & $\begin{array}{l}0.78 \mathrm{ma}-0.9 \mathrm{Ma} \text { (paleomag, } \\
\text { dinos) } 64.42 \mathrm{mbsf}\end{array}$ & $\begin{array}{l}0.254 .0 .78 \mathrm{Ma} \text { (nannos, } \\
\text { paleomag) } 65-62.3 \mathrm{mbsf}\end{array}$ & $\begin{array}{l}0.46 \mathrm{Ma} \text { (nannos) } \\
324.86 / 333.63 \mathrm{mbsf}\end{array}$ \\
\hline \multirow[t]{3}{*}{$\mathrm{pp} 4(\mathrm{~s})$} & Above & $>1.4 \mathrm{Ma}($ dinos$) 129.15 \mathrm{mbsf}$ & $>1.4 \mathrm{Ma}($ dinos $) 145.36 \mathrm{mbsf}$ & \\
\hline & Depth & $37 \mathrm{mbsf}$ & $155 \mathrm{mbsf}$ & At or above $519.8 \mathrm{mbsf}$ \\
\hline & Below & $1.4-7.4 \mathrm{Ma}$ (dinos) $138 \mathrm{mbsf}$ & $1.4-7.4 \mathrm{Ma}($ dinos$)$ & $1.7 \mathrm{Ma}$ \\
\hline \multirow[t]{3}{*}{$\mathrm{m} 0.5(\mathrm{~s})$} & Above & & & \\
\hline & Depth & $>256.36 \mathrm{mbsf}$ & & \\
\hline & Below & $>8.6 \mathrm{Ma}($ dinos $) 256.36 \mathrm{mbsf}$ & & \\
\hline \multirow[t]{3}{*}{ PFS } & Above & & $\begin{array}{l}0.78-0.9 \mathrm{Ma} \text { (paleomag, } \\
\text { nannos) } 65-75.2 \mathrm{mbsf}\end{array}$ & \\
\hline & Depth & & $75.2 \mathrm{mbsf}$ & \\
\hline & Below & & & \\
\hline \multirow[t]{3}{*}{ LMFS } & Above & 5.9-7.4 Ma (dinos) $163.11 \mathrm{mbsf}$ & 5.9-7.4 Ma (dinos) $244.4 \mathrm{mbsf}$ & \\
\hline & Depth & $171 \mathrm{mbsf}$ & $246 \mathrm{mbsf}$ & \\
\hline & Below & 5.9-7.4 Ma (dinos) $172 \mathrm{mbsf}$ & 5.9-7.4 Ma (dinos) $249 \mathrm{mbsf}$ & \\
\hline
\end{tabular}

\subsubsection{The pp3(s) sequence boundary}

The pp3(s) sequence boundary is bounded below by offlapping reflections and above by subhorizontal, high-amplitude reflections (Figs. 2, 3 and 8). At ODP Sites 1071 and 1072, this sequence boundary separates homogeneous clayey-silts below from thinly interbedded sandy-silts and clayey-sands above. Biostratigraphy and paleomagnetics constrain the age of strata below pp3(s) to as young as $0.46 \mathrm{Ma}$, while overlying strata are as old as $0.25 \mathrm{Ma}$ (Table 1). Like the underlying sequence boundaries, the pp3(s) surface is interpreted as an erosional unconformity formed during regression that was modified by erosion due to shoreface retreat during transgression.

\subsection{Flooding surfaces}

\subsubsection{Late Miocene flooding surface}

The late Miocene flooding surface is a flooding surface at seismic resolution and a fining-upward interval of approximately $10 \mathrm{~m}$ thickness at core resolution (Figs. 2, 4-6). The reflection dips seaward and separates underlying high-amplitude reflections from overlying low-amplitude reflections near ODP Sites 1071 and 1072 (Figs. 2, 3 and 8). At Hole 1071C, recovered sediments grade upward from pebbly- muddy-sand to sandy- and silty-clay across the reflection (Core 174A-1071C-16X to $15 \mathrm{X})$. This trend is associated with an abrupt upward increase in gamma ray values (Fig. 6). At Hole 1072A, recovered sediments grade from poorly sorted medium-grained sands to very fine muddysands across this reflection (Core 174A-1072A46R) and are associated with increasing-upward gamma ray values (Fig. 7). Biostratigraphy constrains the late Miocene flooding surface to between 7.4 and $5.9 \mathrm{Ma}$ (Table 1); no hiatus is resolved at this surface. 


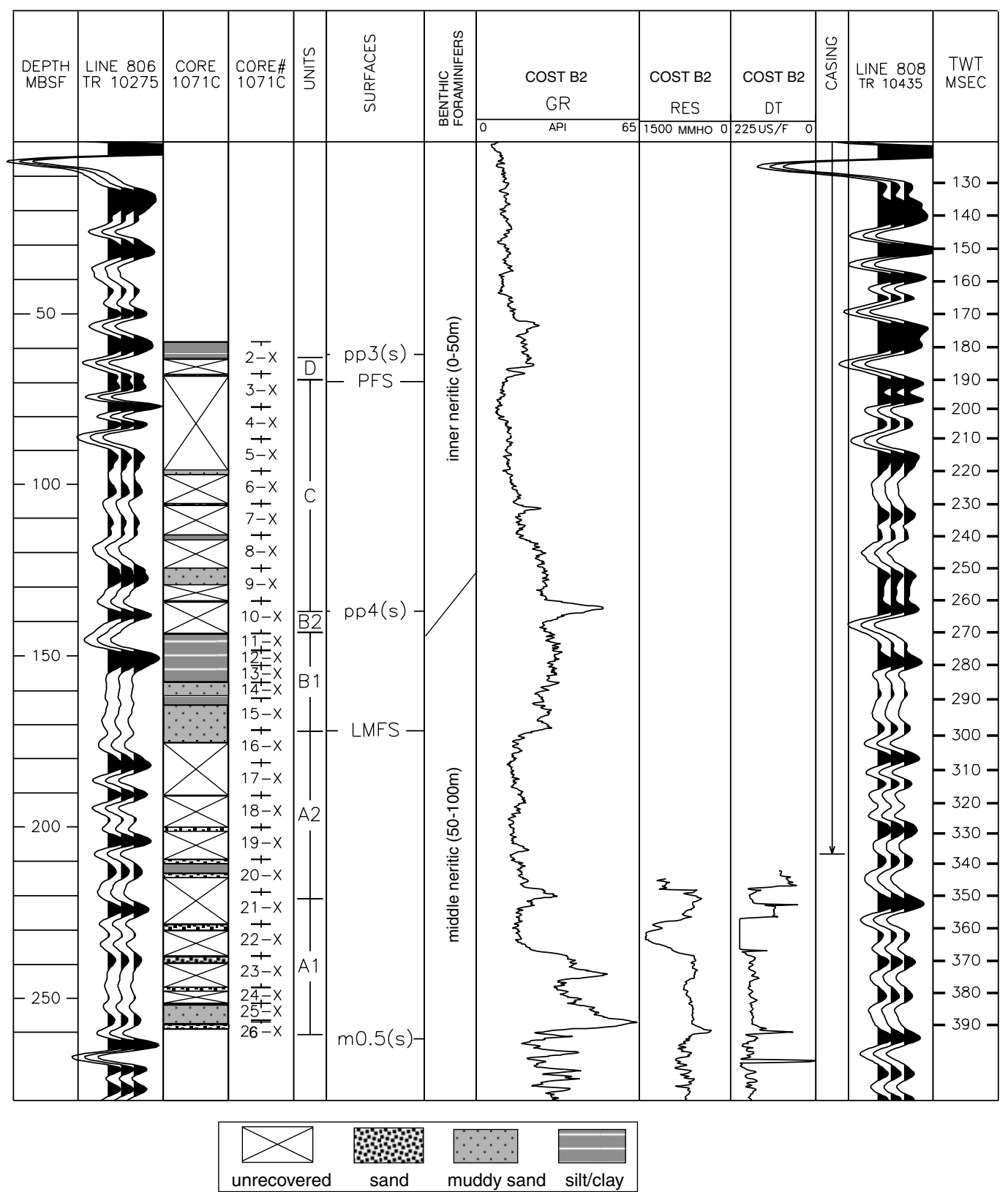

Fig. 6. Integration of seismic, wireline, and core data in vicinity of Site 1071. Hole 1071C core data are used in conjunction with the COST B2 wireline logs (located in Fig. 1B). DEPTH-All data are referenced in mbsf (meters below the sea floor). LINE 806-Seismic trace from cdp 10275 that is located closest to Hole 1071C. CORE-Core lithology and recovery at Hole 1071C; CORE \#-Core barrel number at Hole 1071C; UNITS—lithologic units; SURFACES—sequence boundaries (m0.5(s), pp4(s), and pp3(s)), late Miocene flooding surface (LMFS), and Pleistocene flooding surface (PFS) picked based on COST B2 log character. BENTHIC FORAMINIFERS-used to constrain paleobathymetry. GR, RES, and DT are the gamma ray, resistivity, and sonic wireline logs from the COST B-2 borehole ( $\sim 950 \mathrm{~m}$ south-southwest from Hole 1071C, Fig. 1B). CASING - the COST B2 gamma ray log was run through casing above 207.8 mbsf. LINE 808 -Seismic trace from cdp 10435 that is located closest to the COST B2 borehole. TWT-two way travel time based on ODP Site 1072 checkshot survey. Core data are derived from Austin et al. (1998). 


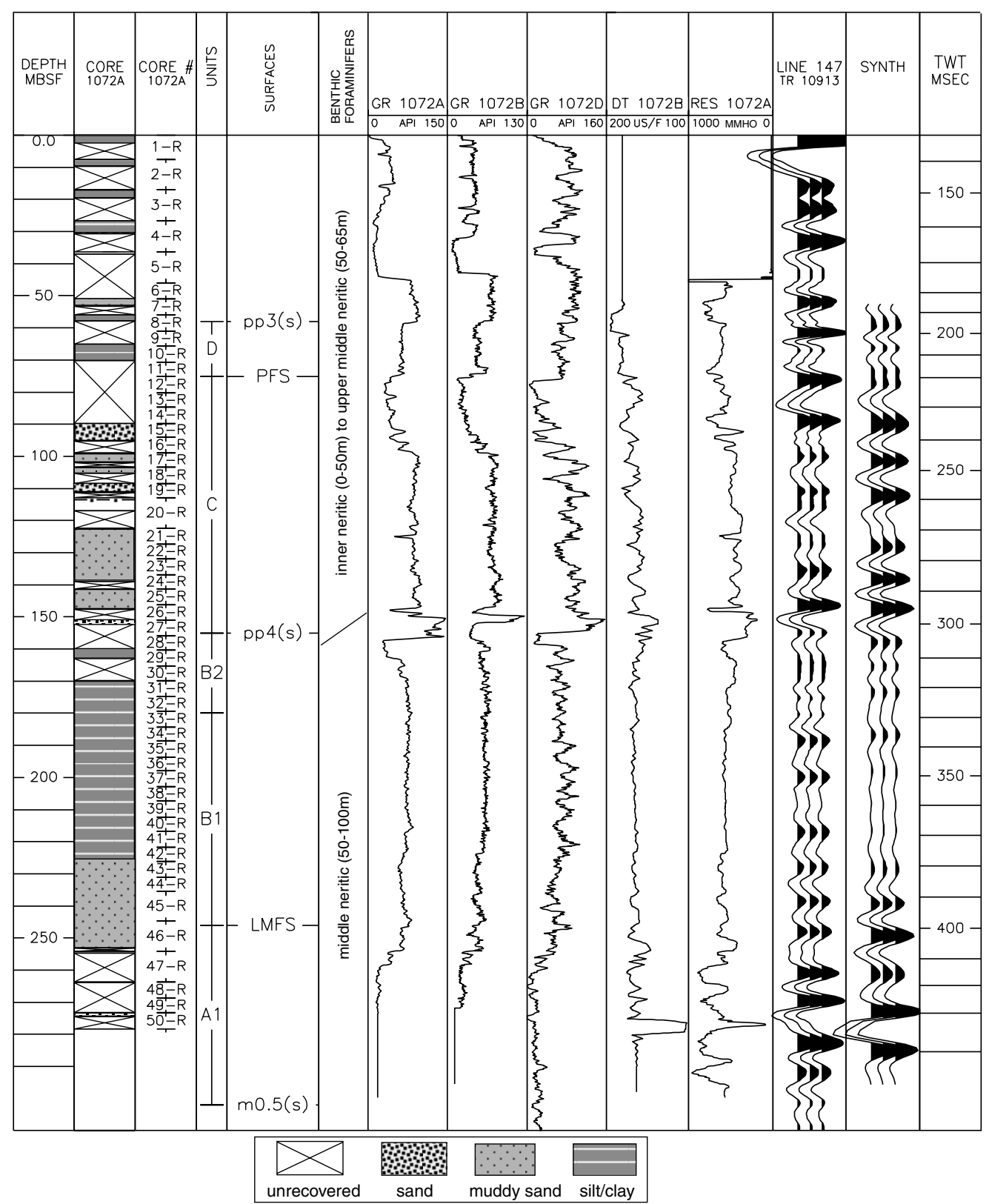

Fig. 7. Integration of seismic, wireline, and core data in vicinity of Site 1072 (located in Fig. 1B). DEPTH-All data are referenced in mbsf (meters below sea floor). CORE—Core lithology and recovery at Hole 1072A; CORE \#-core barrel number for Hole 1072A; UNITSlithologic units; SURFACES—-sequence boundaries (m0.5(s), pp4(s), and pp3(s)), late Miocene flooding surface (LMFS), and Pleistocene flooding surface (PFS). BENTHIC FORAMINIFERS - used to constrain paleobathymetry. GR1072A wireline gamma ray log from Hole 1072A; GR 1072B - wireline gamma ray log from Hole 1072B; GR 1072D—gamma ray LWD (logging-while-drilling) for Hole 1072D. DT 1072B - wireline sonic log from Hole 1072B. RES 1072A - wireline resistivity log for Hole 1072A. LINE 147-Seismic trace from cdp 10913 that is located closest to Hole 1072B. SYNTH - Synthetic seismogram was generated from an 80-Hz, minimum phase, Ricker wavelet convolved with reflection coefficients derived from a despiked sonic $\log$ (bulk density was assumed to be constant and equal to $2.0 \mathrm{~g} / \mathrm{cm}^{3}$ ). TWT - two way travel time based on ODP Site 1072 checkshot survey. Core data are derived from Austin et al. (1998). 


\subsubsection{Pleistocene flooding surface}

The Pleistocene flooding surface dips seaward and separates high-amplitude, seaward-merging reflections below from low-amplitude reflections above (Figs. 2 and 3). At ODP Site 1072, this flooding surface is represented by an abrupt upward increase in gamma ray values (Fig. 7) representing gradation of muddy-sands to homogeneous silty-clays. The biostratigraphic age constraint for this surface is $0.9-$ $0.78 \mathrm{Ma}$ (Table 1).

\subsection{Units of the late Miocene-Pliocene sequence}

\subsubsection{Unit $A_{1}$}

Unit $A_{1}$ is a progradational succession bounded below by $\mathrm{m} 0.5(\mathrm{~s})$ and above by a thin flooding interval that marks the boundary between units $A_{1}$ and $A_{2}$ (Figs. 2, 3 and 6). It has high-amplitude reflections that are subhorizontal landward of ODP Site 1071 and dip at increasing angles in the vicinity of the m0.5(s) clinoform rollover (Figs. 2 and 3). Near the $\mathrm{m} 0.5(\mathrm{~s})$ clinoform rollover, these reflections offlap against the overlying unit and downlap onto $\mathrm{m} 0.5(\mathrm{~s})$. Unit $\mathrm{A}_{1}$ can be traced over the clinoform rollover to the toe-of-slope as a group of seawarddipping reflections (Fig. 8).

Within unit $\mathrm{A}_{1}$, the COST $\mathrm{B} 2$ gamma ray log exhibits two upward-decreasing gamma ray successions superimposed on an overall decreasing-upward gamma ray signature (Fig. 6). At Hole 1071C, just above $\mathrm{m} 0.5(\mathrm{~s})$, there is a zone of indurated, poorly sorted, medium to coarse-grained, pebbly glauconitic sand with pebbles $2-4 \mathrm{~cm}$ in diameter (Core-174A1071C-26X). This bed has a wireline log response of high gamma ray values, high resistivity, and high velocity (Fig. 6). Unit $A_{1}$ grades upward from bioturbated, micaceous, glauconitic sandy-clay and sandysilt with scattered shell fragments, organic fragments, and pebbly zones (Core 174A-1071C-25X) to poorly sorted, silty-sand (Core 174A-1071C-24X) to poorly sorted, interbedded silty-sand and silty-clay with scattered shell fragments and wood fragments (Core 174A-1071C-22X). No recovery in Core 174A1071C-21X coincides with the onset of low gamma ray values that suggests the upper part of unit $A_{1}$ is sand-prone (Fig. 6). The upper boundary of unit $A_{1}$ at Hole 1071C consists of bioturbated silty-sand and silty-clay with shell fragments, scattered sand-filled burrows and pebbles (Core 174A-1071C-20X).

At ODP Site 1072 , unit $A_{1}$ gamma ray $\log$ values are low and uniform (Fig. 7). Unit $A_{1}$ consists of indurated, glauconitic, pebbly sand (Core 174A1072A-50R to 49R), poorly sorted, micaceous sandy-mud (Core 174A-1072A-48R) and very poorly sorted glauconitic, silty, medium sand (Core 174A1072A-47R). The cemented sand of Core 174A1072A-50R ties to a resistivity spike, high sonic values, and a high-amplitude seismic trough (Fig. 7). At the 684-1 borehole, unit $A_{1}$ has a gamma ray $\log$ character of low, blocky values that increase upward. This suggests a sand-prone lithology with increasing silt/clay content upward (Fig. 8).

On the paleo-shelf (landward of the m0.5(s) clinoform rollover) unit $A_{1}$ was deposited in inner neritic depths (Fig. 6). It grades upward and seaward from clay and silt sediments interpreted to have been deposited from suspension to sandy sediments deposited by traction-driven currents. Sands seaward of the clinoform rollover are interpreted as sediment-gravity flows.

\subsubsection{Unit $A_{2}$}

Unit $A_{2}$ is wedge-shaped, thins seaward, and is restricted to the paleo-shelf (Figs. 2, 3 and 8). It is bounded below by the top of unit $\mathrm{A}_{1}$ and above by the late Miocene flooding surface. Seaward of Hole 1071C, internal reflections have high-amplitudes, are seaward dipping, and downlap onto unit $A_{1}$. Unit $\mathrm{A}_{1}$ is not present at ODP Site 1072 because it has pinched out (Figs. 2, 3 and 8). In strike view, reflections are subhorizontal (Fig. 4). Landward of Hole $1071 \mathrm{C}$, lens-shaped features present in dip section have an average width of $\sim 2 \mathrm{~km}$ (Figs. 2 and 3 ). These features are thickest $(\sim 25 \mathrm{~m})$ near profile 145 and thin to the north $(\sim 15 \mathrm{~m})$. Each of these lensshaped features consists of high-amplitude reflections at their boundaries with internal low-amplitude, seaward-dipping, infill (Figs. 2 and 3).

At the COST B2 borehole, unit $\mathrm{A}_{2}$ consists of low gamma ray values above a basal zone of higher gamma ray values (Fig. 6). Low recovery at Hole 1071C suggests high sand content. Sediments from Hole 1071C consist of glauconitic silty-sand (Core 174A-1071C-19X), well-sorted, pebbly gravel of mixed lithology with shell fragments resting with 
sharp contact above a well-sorted, silty, medium sand (Core 174A-1071C-18X), and poorly sorted, glauconitic, medium sand with scattered pebbles (Core 174A-1071C-16X) (Fig. 6).

Unit $\mathrm{A}_{2}$ is a sand-prone succession bounded by flooding surfaces. It is interpreted as an inner neritic deposit based on its coarse grain size and its relation to the overlying middle neritic silts and clays of unit $\mathrm{B}_{1}$ (Fig. 6). Coarse sands and pebbles in unit $\mathrm{A}_{2}$ (ODP Site 1071) tie to the seaward edge of lens-shaped features in updip seismic sections (Figs. 2 and 3). The lens-shaped features are interpreted to represent nearshore sand ridges or bars (Rine et al., 1986).

\subsubsection{Unit $B_{1}$}

Unit $B_{1}$ is an upward-fining succession that is present across the study region (Fig. 8). It is characterized by low seismic amplitudes that probably arise from the small impedance contrasts within this lithologically homogenous unit (Fig. 7). As a result, acoustic multiples from overlying strata overprint this unit and it is difficult to resolve internal stacking patterns (Figs. 2, 3 and 8). Unit $\mathrm{B}_{1}$ fines upward at Hole 1071C, and has increasing-upward gamma ray values in the COST B2 and ODP Site 1072 logs (Figs. 6 and 7). Cores consist of homogeneous silty-clay and fine sand with sand-filled burrows and shell fragments (Core 174A-1071C-15X), that grade upward into thickly and thinly interbedded silty-clay and clayey-silt (Core 174A-1071C-14X to 13X), to homogeneous silty-clay with minor sandy-silt (Core 174A-1071C$12 \mathrm{X}$ to $11 \mathrm{X}$ ). At ODP Site 1072, cores consist of bioturbated, micaceous, very fine muddy-sand (Core 174A-1072A-46R through 42R) that grades upward to bioturbated, homogeneous, micaceous, silty-clay (Core 174A-1072A-41R through 35R) (Fig. 7) to sandy-mud and silty-clay with fine sand with wood and pyrite nodules (Core 174A-1072A-34R to 33R). At the 684-1 borehole, unit $B_{1}$ is only $20 \mathrm{~m}$ thick and has high, variable gamma ray values (Fig. 8).

Benthic foraminifers suggest that unit $B_{1}$ was deposited in middle neritic water depths $(50-100 \mathrm{~m})$ at ODP Sites 1071 and 1072 (Figs. 6 and 7). Upwarddeepening through the unit is inferred from upwardfining observed in the cores and implied by the gamma ray log character.

\subsubsection{Unit $B_{2}$}

Unit $\mathrm{B}_{2}$ thickens seaward, is thickest near the 684-1 borehole, and is almost pinched out at the COST B2 borehole (Fig. 8). It is bounded below by the interval of maximum flooding that caps unit $\mathrm{B}_{1}$ and above by pp4(s) (Fig. 8). It has an overall upward-coarsening trend.

Between ODP Sites 1071 and 1072, unit $B_{2}$ is thin $(5-20 \mathrm{~m})$ and is characterized by low seismic amplitudes (Figs. 2 and 3). Seaward of ODP Site 1072, this unit thickens to $\sim 300 \mathrm{~m}$ and is characterized by seaward-dipping reflections. At the 684-1 borehole, unit $\mathrm{B}_{2}$ has a decreasing-upward gamma ray log signature (Fig. 8). High gamma ray values at its base tie to low seismic amplitudes and low gamma ray values at its top tie to high seismic amplitudes (Fig. 8). This suggests that the $200 \mathrm{~m}$ thick sands present at the 6841 borehole (inferred from low gamma ray values) are restricted to the seaward part of unit $\mathrm{B}_{2}$ (Fig. 8). Dipping reflections all offlap from the pp4(s) sequence boundary (Fig. 8).

The base of unit $B_{2}$ is defined by the presence of distinct sand interbeds in Hole 1071C and Hole 1072A, and by the shift from upward-fining and increasing gamma ray $\log$ values of unit $\mathrm{B}_{1}$ to upward-coarsening and decreasing $\log$ values (unit $\mathrm{B}_{2}$ ) (Figs. 2, 3 and 8). COST B2 gamma ray values are high and decrease upward in unit $\mathrm{B}_{2}$ (Fig. 6). Core at this location (Hole 1071C) consists of siltyclay with minor sand (Core 174A-1071C-11X); the lack of recovery in Core 174A-1071C-10X suggests that sand content increases upward in this unit. At Hole 1072A, unit $B_{2}$ is thicker $(\sim 20 \mathrm{~m})$, and has gamma ray values that decrease abruptly over the uppermost $5 \mathrm{~m}$ (Fig. 7). At this location sediments grade upward from interbedded silty-clay and sandy-silt with pyrite, siderite, and wood fragments (Core 174A-1072A-32R to $31 \mathrm{R}$ ) to sandy-silt interbedded with fine sand with wood and shell fragments (Core 174A-1072A-30R to 29R). The zone of lowest gamma ray values ties to unrecovered core that supports an interpretation of high sand content (Fig. 7).

Unit $\mathrm{B}_{2}$ is a shoaling-upward succession. The underlying unit $\mathrm{B}_{1}$ reached middle neritic depths and the overlying pp4(s) sequence boundary most likely recorded subaerial exposure. 


\subsubsection{Evolution of the late Miocene-Pliocene sequence}

The $\mathrm{m} 0.5(\mathrm{~s})$ sequence boundary was formed by a relative sea level fall that probably subaerially exposed the shelf margin (Fig. 9A). The overlying units $A_{1}, A_{2}$, and $B_{1}$ record a deepening succession during which the shoreline backstepped (Fig. 9B). Units $A_{1}$ and $A_{2}$ record two progradational pulses within this overall backstepping succession (Fig. 9B). Maximum water depth is inferred at the top of unit $\mathrm{B}_{1}$ (Fig. 9B). Unit $\mathrm{B}_{2}$ records a shallowingupward and progradational succession that was deposited coincidentally with bypass and erosion in the landward zone (Fig. 9C).

\subsection{Pleistocene sequence}

\subsubsection{Unit $C$}

Unit $\mathrm{C}$ is a shoaling-upward succession bounded below by pp4(s) and above by the Pleistocene flooding surface (Fig. 8). Unit $\mathrm{C}$ is thickest $(\sim 100 \mathrm{~m})$ in the vicinity of Sites 1071 and 1072 and thins seaward to $\sim 20 \mathrm{~m}$ at the $684-1$ borehole (Fig. 8). The base of unit $\mathrm{C}$ is recorded by subhorizontal seismic reflections (Figs. 2 and 3). Overlying, seaward-dipping reflections are steepest near ODP Site 1071 and have decreasing inclination toward ODP Site 1072. The first water bottom multiple obscures the base of these dipping reflections.

At the COST B2 borehole, gamma ray log values decrease upward in unit $\mathrm{C}$ (Fig. 6). Lithology at Hole $1071 \mathrm{C}$ grades upward from thinly interbedded clayeysilt and fine sand with irregular contacts (Core 174A1071C-9X), to silty-sand with lenticular sand beds, slumps, and inclined contacts (Core 174A-1071C$8 \mathrm{X})$, to fine sand interbedded with fine micaceous and glauconitic sandy-clay (Core 174A-1071C-7X) to sandy-clay with interbedded micaceous, glauconitic, fine sands (Core 174A-1071C-6X) (Fig. 6). Unrecovered intervals correspond to low gamma ray $\log$ values and are inferred to record sand-prone sediments. The decreasing-upward gamma ray log character at the COST B2 corresponds to seaward-dipping reflections (Figs. 2 and 3).

At Hole 1072A, gamma ray log values also decrease upward in unit C (Fig. 7). Recovered sediments grade upward from homogeneous muddysand and poorly sorted glauconitic sandy-mud, with scattered pebbles, and shell fragments (Core 174A1072A-25R to $24 \mathrm{R}$ ), to poorly sorted, glauconitic, medium to coarse clayey-sand (Core 174A-1072A$23 \mathrm{R}$ to $22 \mathrm{R}$ ), to thickly and thinly interbedded, fining-upward beds of micaceous sandy-mud and muddy-sand with occasional pebbles and granules (Core 174A-1072A-22R to 20R) to micaceous sandy-mud with wood fragments (Core 174A1072A-19R to 17R), to micaceous muddy-sand with evidence of slumping (Core 174A-1072A-15R) (Fig. 7). Above, no recovery and low gamma ray values indicate high sand content. At the 684-1 borehole, gamma ray log values are high within unit $\mathrm{C}$ (Fig. 8).

Unit $\mathrm{C}$ records progradation of a deltaic system over the glauconitic transgressive ravinement surface formed during flooding of the underlying $\mathrm{pp} 4(\mathrm{~s})$ sequence boundary. There is considerable evidence of slumping in core and seismic geometry that suggests significant loss of sediment from the shallow paleo-shelf to the deep shelf and slope.

\subsubsection{Unit D}

Unit $\mathrm{D}$ is bounded below by the Pleistocene flooding surface and above by the pp3(s) sequence boundary. It is wedge-shaped and thickens in a seaward direction (Fig. 8). Internal reflections are sub-parallel, generally low-amplitude, seaward-dipping and can be traced to the slope (Fig. 8). These reflections offlap from the pp3(s) sequence boundary.

At Hole $1071 \mathrm{C}$, unit D is thin and consists of homogeneous olive gray silty-clay (Core 174A-1071C-2X) (Fig. 6). At ODP Site 1072, unit D gamma ray values are high and uniform (Fig. 7). Sediment at Hole 1072A (Core 174A-1072A-11R to 9R) consists of homogeneous, bioturbated, light greenish gray siltyclay (Fig. 7). At the 684-1 borehole, the base of unit D records abruptly increasing gamma ray values over $\sim 30 \mathrm{~m}$. (Fig. 8). Above this, the majority of unit D consists of uniform low values (60-190 mbsf). Unfortunately, it is difficult to interpret this interval because this log was run through casing and, as a result, the gamma ray values are attenuated (Fig. 8). The basal zone of upward-increasing gamma ray values records a deepening-upward interval over $\sim 20 \mathrm{~m}$ above the Pleistocene flooding surface. However, the interval of maximum flooding cannot be identified because of the casing problem. We suggest, based on the 684-1 gamma ray log character 


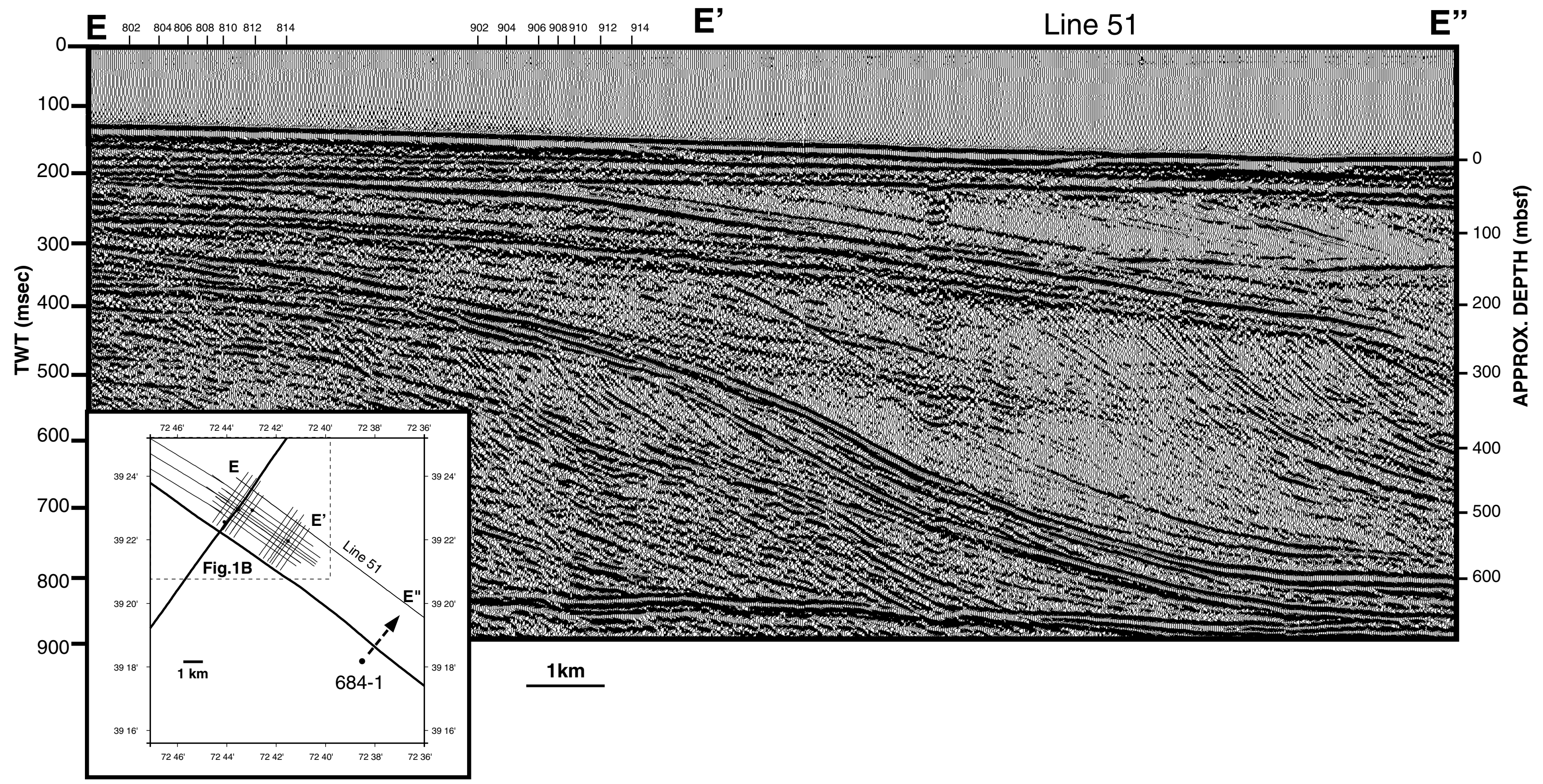

Fig. 8. Regional dip-oriented Oceanus seismic profile E-E'-E'. (A) Uninterpreted. This extends seaward from the study region shown in Fig. 1 (B) (B)

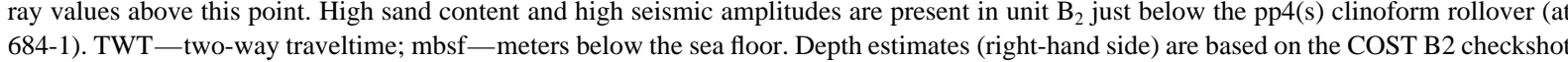
survey corrected for water depth at the 684-1 borehole. 


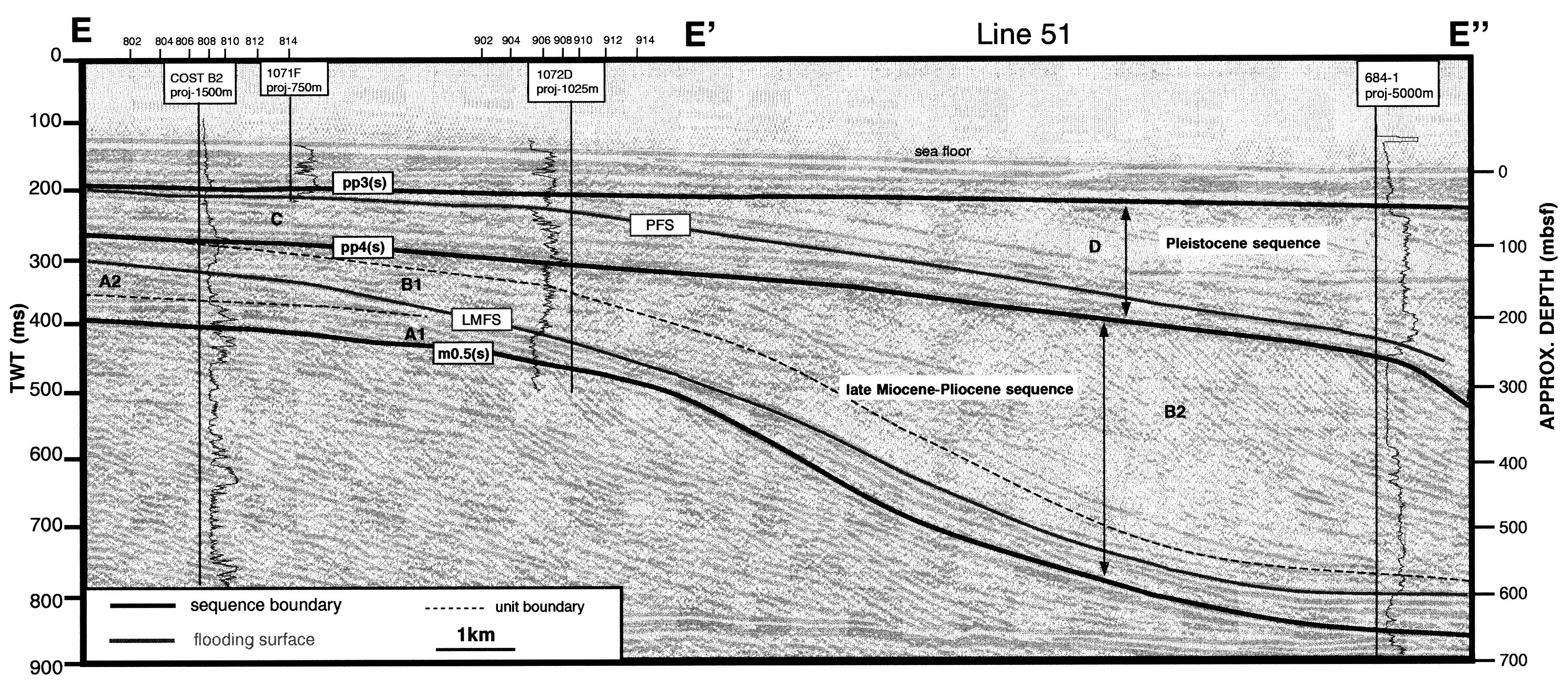

Fig. 8. (continued) 

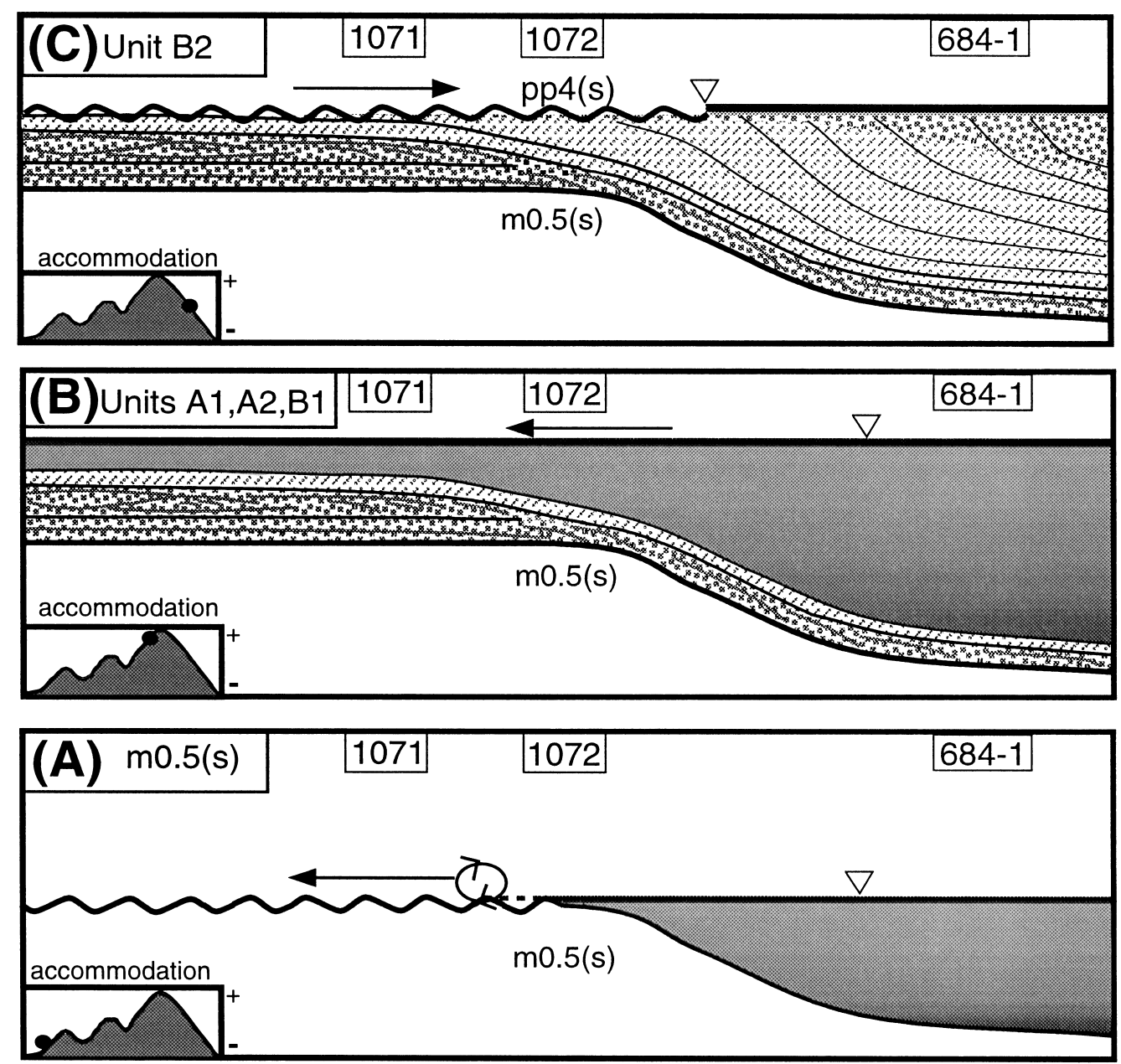

\begin{tabular}{|c|c|c|c|}
\hline silt/clay & 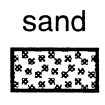 & shoreline movement & $\begin{array}{l}\text { shoreface } \\
\text { erosion } \\
\text { sea level }\end{array}$ \\
\hline
\end{tabular}

Fig. 9. Evolution of the late Miocene-Pliocene sequence. (A) During sea-level rise, the m0.5(s) paleo-shelf was flooded. (B) There was an overall increase in accommodation during which units $\mathrm{A}_{1}, \mathrm{~A}_{2}$, and $\mathrm{B}_{1}$ were deposited. (C) After this transgression, a deltaic system prograded into the study region (unit $\mathrm{B}_{2}$ ). 
and line 51 seismic character, that unit $\mathrm{D}$ is dominated by homogeneous silt/clay similar to core recovered at ODP Site 1072 (Fig. 8).

Unit $D$ is a seaward-thickening, fine-grained, progradational succession. Benthic foraminifers suggest deposition in upper middle neritic (50$65 \mathrm{~m}$ ) depths at ODP Site 1072 (Fig. 7).

\subsubsection{Evolution of the Pleistocene sequence}

The pp4(s) sequence boundary was formed by bypass and erosion of the shelf margin during progradation; subsequent transgression flooded this surface (Fig. 10A). Unit $\mathrm{C}$ is a shoaling upward succession formed by progradation of a delta over this flooding interval (Fig. 10B). It is capped by a second deepening event, the Pleistocene flooding surface. Unit D was then deposited by a system that prograded over the Pleistocene flooding surface (Fig. 10C).

\section{Discussion}

The late Miocene-Pliocene and Pleistocene sequences have similar features. They both lack lowstand wedge deposits, they contain higher order cyclicity, and there is little evidence of significant channel incision. There are also distinct differences between the sequences. The late Miocene-Pliocene sequence spans $7 \mathrm{~m} . \mathrm{y}$., deepens upward over most of the paleo-shelf (units $\mathrm{A}_{1}, \mathrm{~A}_{2}, \mathrm{~B}_{1}$ ), and has an overlying progradational deposit restricted mainly seaward of the underlying clinoform rollover (unit $\mathrm{B}_{2}$ ). In contrast, the Pleistocene sequence spans only 1.5 m.y., deepens abruptly near its base, shoalsupward (unit C), and then deepens again (unit D). The Wheeler diagram honors the sparse age data available (Table 1) and illustrates our vision of how time is distributed through these sequences (Fig. 11).

\subsection{Depositional model of sequence architecture}

We constructed a geometric model to gain insight into the eustatic history that controlled the evolution of the late Miocene-Pliocene sequence (Fig. 12). The model is similar to those of Jervey (1988) and Reynolds et al. (1991). It is constrained by the geometry and duration of the late Miocene-Pliocene sequence. In the model, sediments landward of the clinoform rollover are deposited so that the sea floor forms a horizontal surface; sediments seaward of the clinoform rollover are deposited at a dip of $3.5^{\circ}$ (the average dip of the deposits) (Fig. 12). Sediment flux is sourced on the landward (left) edge and is $70 \mathrm{~m}^{2} /$ year throughout the simulation. The flux is estimated by dividing the cross-sectional area of the late Miocene-Pliocene sequence $\left(490 \times 10^{6} \mathrm{~m}^{2}\right)$ by the total duration of the sequence (7 m.y.) (Fig. 12).

The accommodation history is the key parameter that controls the stratigraphic architecture that results from the model. The horizontal surface that sediments fill to is termed baselevel, and the history of baselevel change is the accommodation history. In the model, the clinoform rollover always reaches the baselevel surface. As the rate of change in accommodation increases or decreases, the clinoform rollover will shift landward or seaward (under the condition that the sediment flux entering the model is constant).

We simulated the stratigraphic evolution of a sequence such as the early Miocene-Pliocene sequence with an accommodation history that increased rapidly to a maximum after 4.5 m.y. and then decreased a small amount before it increased again from 7.25 to 7.5 m.y. (Fig. 12A). We chose this history because it best reproduced the stratal architecture of the late Miocene-Pliocene sequence (Fig. 9). The key attribute of this accommodation history is that high frequency oscillations in accommodation are superimposed on a long term increase $(\sim 150 \mathrm{~m})$ in accommodation.

This model begins with base-level at the m0.5(s) clinoform rollover $(0 \mathrm{~m} . \mathrm{y}$.$) . During the first rapid$ increase in accommodation (Fig. 12A), the clinoform rollover backsteps (0-3 m.y.) (Fig. 12B). During the subsequent slow increase in accommodation, it progrades (3-4.5 m.y.) (Fig. 12B). The result is a landward-thickening, then landward-thinning succession (Fig. 12B). During the ensuing decrease in accommodation (4.5-7 m.y.), a rapid progradation occurs and underlying strata, originally deposited between 3-3.5 m.y., are eroded and redeposited on the slope. (Fig. 12B). The final increase in accommodation (7-7.5 m.y.) results in a rapid backstepping of the system (Fig. 12C).

The modeled architecture closely resembles the late Miocene-Pliocene sequence architecture. Similarities include a thick transgressive succession on the shelf, 

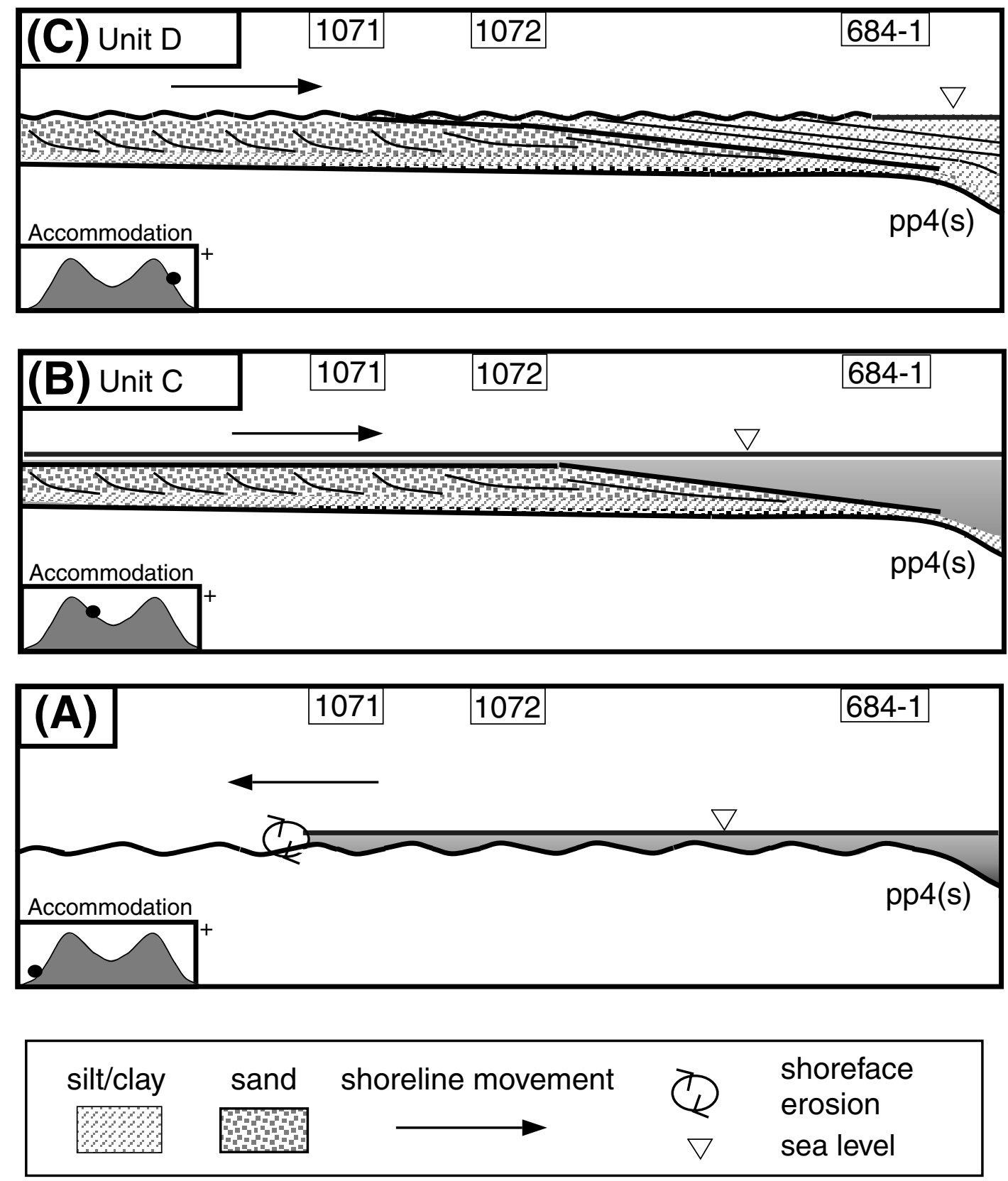

Fig. 10. Evolution of the Pleistocene sequence. (A) Flooding of the pp4(s) sequence boundary resulted in shoreface retreat and additional erosion. (B) After transgression, water depth reached upper-middle neritic (base of unit C) before deltaic progradation occurred (unit C). (C) After deepening associated with the Pleistocene flooding surface, another progradation occurred (unit D). 


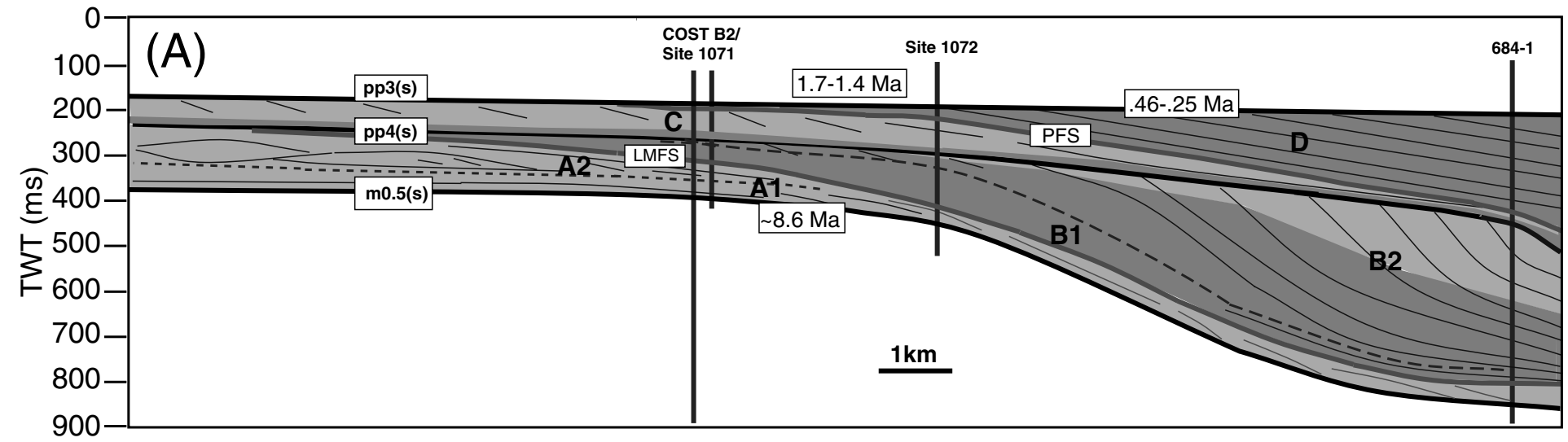

(B)
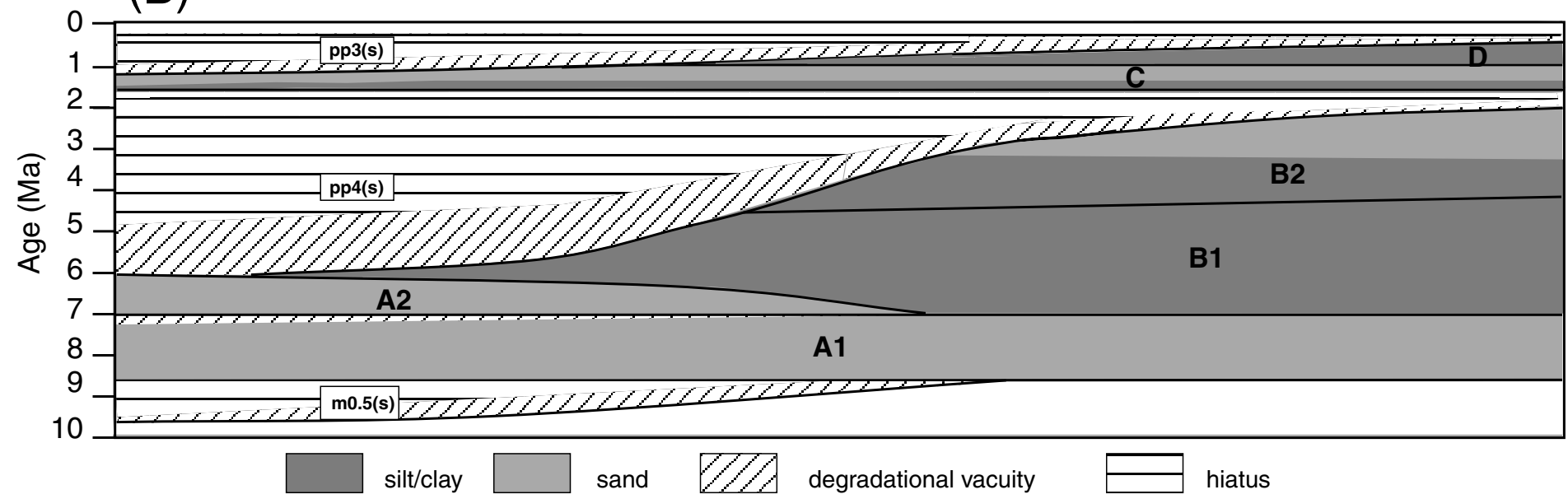

Fig. 11. Summary of dip-oriented interpretation of lithology and chronostratigraphy. Top: Dip section of the interpreted sand/shale composition of the late Miocene-Pliocene and Pleistocene sequences; Bottom: The Wheeler (chronostratigraphic) diagram honors the sparse age data available (Table 1) yet is highly interpretive. 

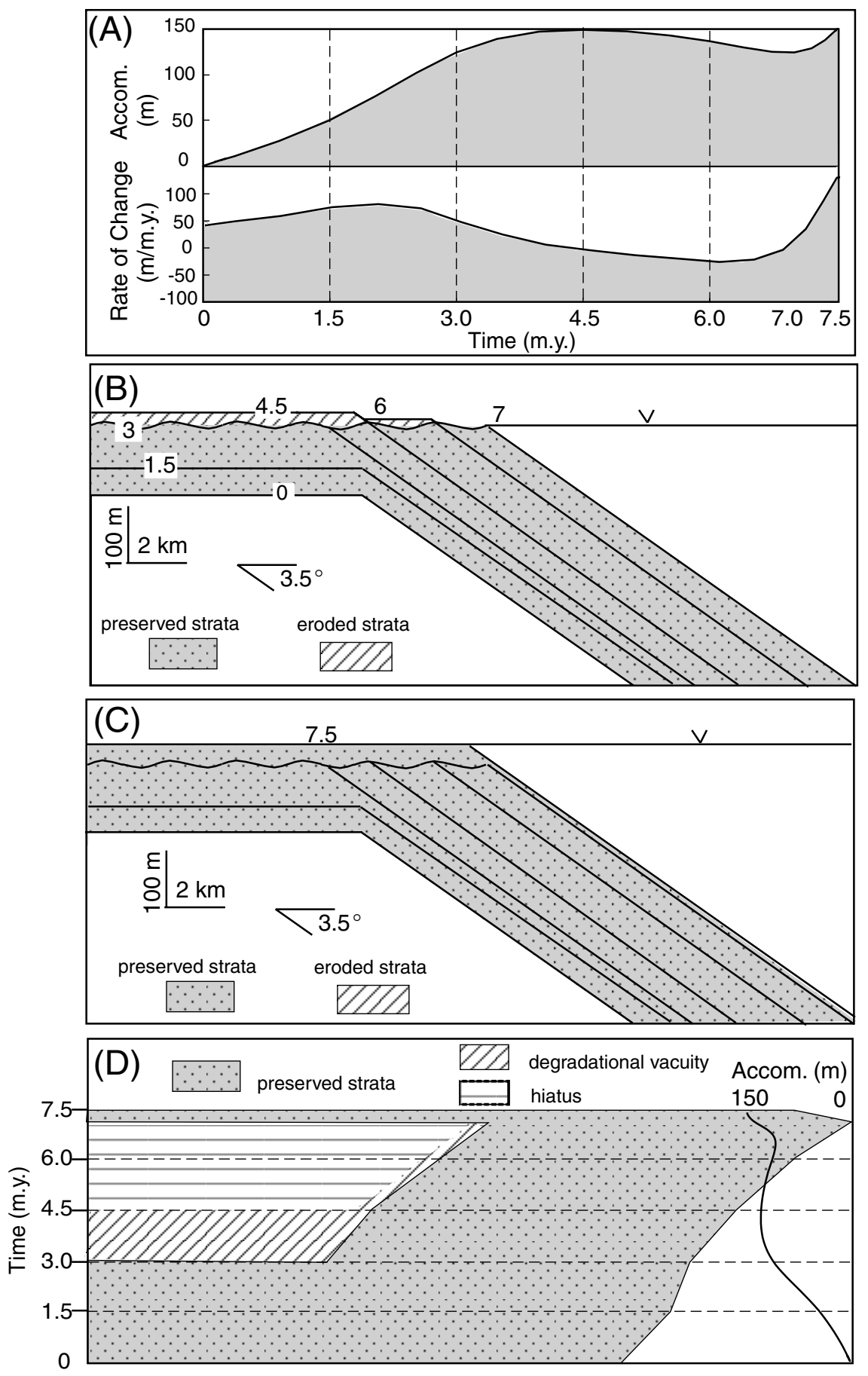

Fig. 12. Depositional model of the late Miocene-Pliocene depositional sequence. (A) Accommodation history proposed to drive late MiocenePliocene sequence. Top: Accommodation history; Bottom: Rate of change in accommodation with time. (B) Lithostratigraphic evolution from 0-7 m.y.; for the first 3 m.y., the clinoform steps landward; between 3-4.5 m.y. sediment progrades; between 4.5 and 7 m.y. sediment progrades and erosion and bypass of the shelf occurs. (C) An increase in accommodation between 7-7.5 m.y. causes deposition on the shelf overlying the sequence boundary. (D) Wheeler diagram. Missing time associated with the sequence boundary decreases seaward due to bypass and erosion. 
overlying regressive deposits that are restricted seaward, no lowstand wedge, and the hiatus associated with sequence bounding unconformities decreases in duration seaward (Fig. 11B vs. Fig. 12D).

Accommodation is driven by isostatic response to sediment and water-loading, compaction of underlying sediments, tectonic subsidence, and eustatic change. Since the New Jersey margin is a late-stage passive continental margin and the rate of tectonic subsidence is extremely low, we infer the dominant control on the creation of accommodation was eustasy. Thus, this model illustrates that eustatic oscillations superimposed on an overall eustatic rise could explain the structure of the Miocene-Pliocene sequence. One key assumption of the model is that sediment flux remained constant through time. If, in fact, sediment supply was not constant, significant progradations and retrogradations could be created with an eustatic history that increased at a constant rate.

\subsection{Comparison to existing models of depositional sequences}

The outstanding characteristic of the late MiocenePliocene sequence is that a thick $(\sim 100 \mathrm{~m})$ transgressive succession is preserved on the shelf. As suggested by the depositional model, this stratigraphic succession could have been formed by high-input sediment flux during eustatic rise (termed "accretionary transgression" by Helland-Hansen and Gjelberg 1994). The parasequences (units $\mathrm{A}_{1}$ and $\mathrm{A}_{2}$ ) within this overall transgressive succession most likely formed by high frequency changes in either sediment supply or sea level superimposed upon a long-term rise in sea level.

Lowstand wedge deposits that onlap the underlying clinoform are not present. We interpret that this was because sea-level did not fall significantly below the clinoform rollover. Sea-level did not fall below the clinoform because the long term rise in sea-level minimized the effect of high frequency sea-level falls and/or because the very high sediment supply caused the shelf to continue to build seaward during sea-level lowstands as opposed to being incised. Alternatively, bypass of lowstand sediment into deeper water might explain the lack of a lowstand wedge.

\subsection{Comparison of New Jersey margin late Miocene- Pleistocone and middle Miocene sequences}

The late Miocene-Pliocene and Pleistocene sequences of this study differ from the underlying middle Miocene sequences studied previously (Fig. 14). Middle Miocene sequences consist of a thick ( $\sim 100-300 \mathrm{~m})$ onlapping lowstand wedge which is overlain by a thin $(20-50 \mathrm{~m})$ highly regressive highstand deposit (Fig. 14A). In contrast, the late Miocene-Pliocene sequence does not have a discrete lowstand wedge that onlaps the underlying sequence boundary and does have a thick transgressive deposit on the paleo-shelf (Fig. 14B). Middle Miocene sequences range from less than 1-2 m.y. in duration (Miller et al., 1996; Miller et al., 1998a; Poulsen et al., 1998) whereas the late Miocene-Pliocene sequence spanned approximately 7 m.y. (Fig. 14).

We attribute the differences between the middle Miocene and late Miocene-Pliocene sequences to result from very different long term (5-10 m.y.) eustatic histories. In the middle Miocene, high frequency eustatic fluctuations superimposed on a long-term eustatic fall resulted in short duration, highly progradational, sequences (Fig. 14A). In contrast, the late Miocene-Pliocene sequence formed during an overall increase in accommodation driven by long term eustatic rise. This accommodation provided the space for thick accumulations of sediment on the shelf and did not allow distinct sequence boundaries to form for $\sim 7$ m.y. in the study region (Figs. 9 and 11). The short duration of the middle Miocene sequences may result from exposure of the shelf during each high-frequency oscillations of sea level. In contrast, during long-term eustatic rise, m.y. fluctuations may be only recorded as parasequences such as are observed in units $A_{1}$ and $A_{2}$ of the late Miocene-Pliocene sequence.

Remarkably different lithofacies distributions are present within these two sequence types (Fig. 14). In middle Miocene sequences, sandy deposits are present in the lowstand wedge where strata onlap the underlying sequence boundary (Fig. 14A). In contrast, in the late Miocene-Pliocene sequence, sandy deposits are located far seaward of the underlying clinoform rollover (Fig. 14B).

The Pleistocene sequence architecture is controlled by its proximity to the present continental slope. The 


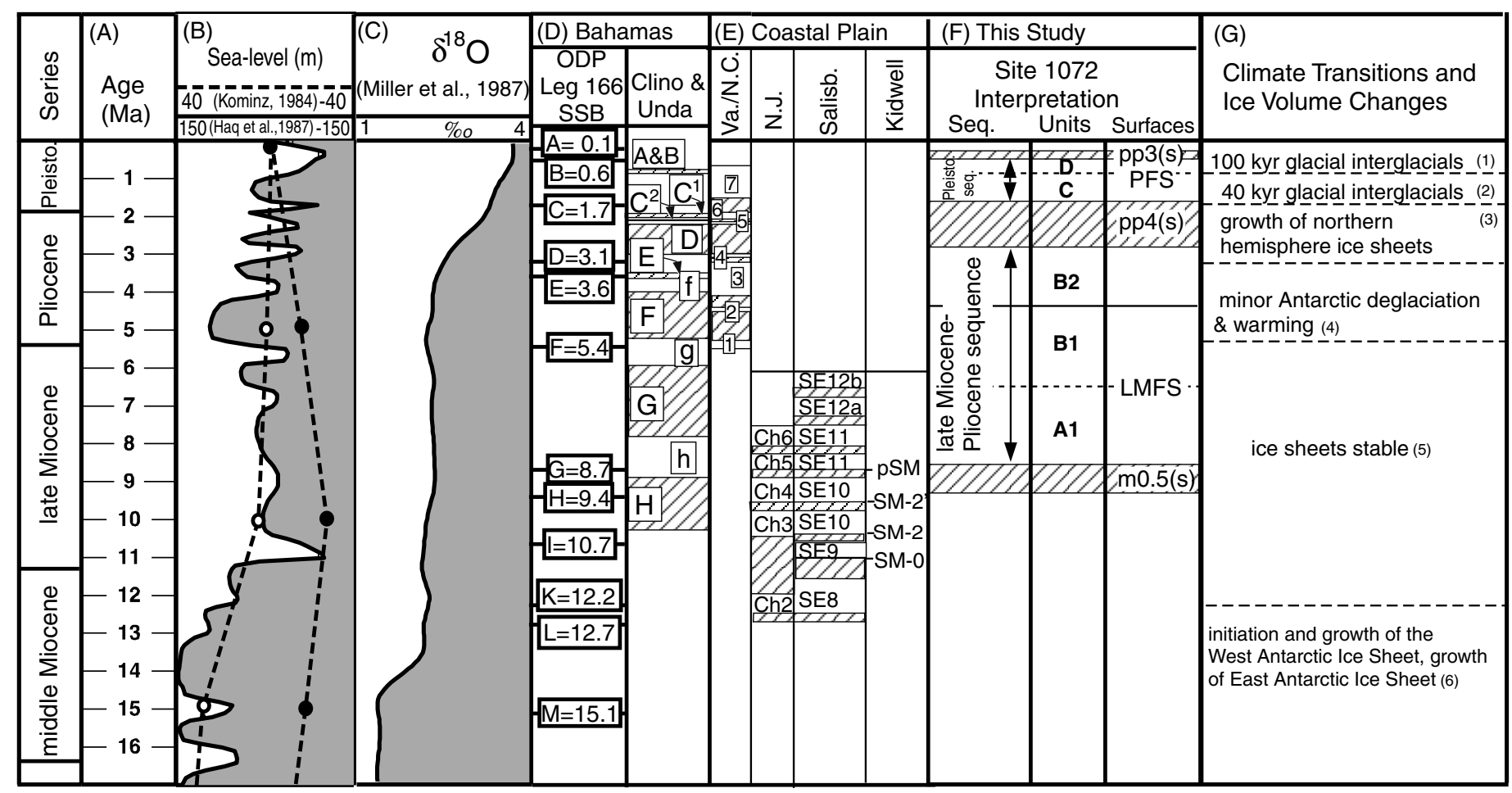

Fig. 13. Correlation of this study to eustasy estimates, and to strata of the North Atlantic coastal plain and the Great Bahama Bank. (A) Ages corrected to Berggren et al. (1995) time scale. (B) Haq et al. (1987) sea-level curve and Kominz (1984) tectono-eustatic curve. Kominz predicted eustatic change resulting from mid-ocean ridge volume changes (solid circles). Kominz (1984) added a linear decrease in sea level from middle Miocene to present to account for ice volume increase due to glaciation (open circles). (C) Composite benthic foraminiferal oxygen isotope record for Atlantic DSDP sites (from Miller et al., 1987, Fig. 1). Miller linearly interpolated at $0.1 \mathrm{~m} . y$. intervals and smoothed to remove frequencies higher than 1.35 cycles/m.y. (D) ODP Leg 166 Seismic sequence boundaries (SSB) on the Great Bahama Bank slope (Eberli et al., 1997). Clino and Unda seismic sequence boundaries (A-H) and seismic sequences (f-h) on the Great Bahama Bank shelf (Eberli et al., 1997). Sequence durations are from a modified Table 1 of Eberli et al. (1997) (Eberli, personal communication)). (E) North Atlantic coastal plain sequences. 'Va./N.C.' summarizes chronology of Pliocene stratigraphy compiled by Krantz (1991): \#1 Upper Eastover Fm.; \#2, \#3, and \#4 = Yorktown Fm.; \#5 = Chowan River Fm; \#6 = Bacons Castle Fm., \#7 = Windsor Fm.. 'N.J.', 'Salisb.', and 'Kidwell' illustrate de Verteuil's (1997) correlations of onshore sequences mapped in New Jersey (NJ) with those he mapped in the Salisbury Embayment (Salisb.) and with those mapped by Kidwell (1997) in the Salisbury Embayment. de Verteuil (1997) had no control on the duration of lacunae in the Ch3-Ch6 interval and assumed minimal missing record. (G) Numbers refer to following references: (1,2) Hodell and Venz (1992), Raymo (1997), and Clark and Pollard (1998). (3) Raymo (1994). (4) (Hodell and Venz (1992) and Shackleton et al. (1995). (5) Abreu and Anderson (1998). (6) (Flower and Kennett (1994), and Abreu and Anderson (1998). 

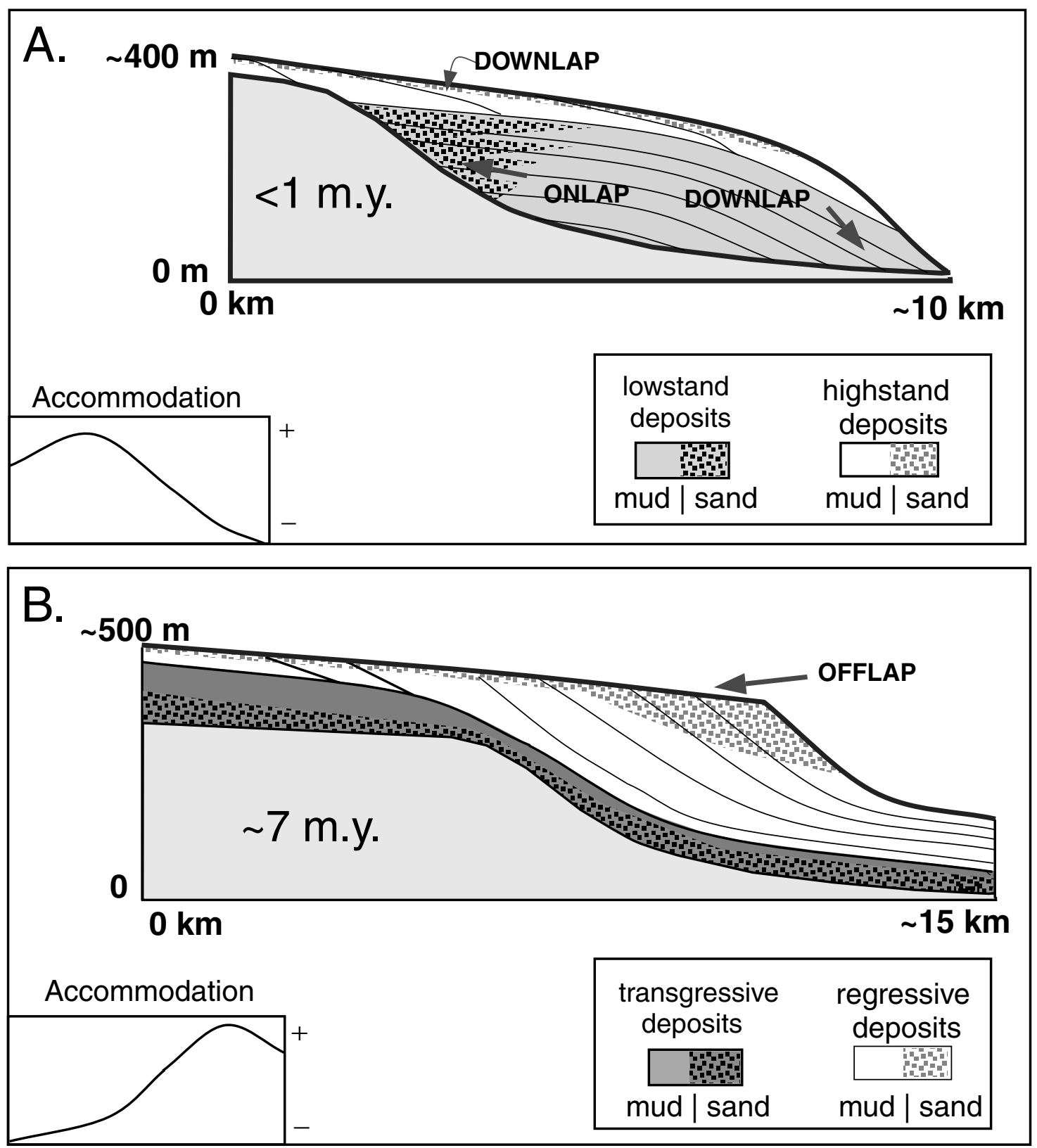

Fig. 14. (A) Typical middle Miocene sequences on the New Jersey Margin contain a discrete lowstand wedge and an overlying highstand deposit (Greenlee and Moore, 1988; Greenlee et al., 1988; Greenlee et al., 1992; Poulsen et al., 1998). (B) The late Miocene-Pliocene sequence does not have a lowstand wedge, has thick transgressive deposits preserved on the paleo-shelf, and has regressive deposits preserved seaward of the underlying rollover. Sand distribution differs markedly in these two sequences. 
Pleistocene sequence was deposited directly on the continental slope over the edge of the Eocene platform. During deposition of this and younger sequences, large amounts of sediment bypassed the continental shelf to the slope (Steckler et al., 1993; Fulthorpe et al., 1996; Mountain et al., 1998). Evidence of this process is recorded in the continuity of unit D reflections from the modern outer shelf to the continental slope (Fig. 8). Thus, lowstand sediment of the Pleistocene sequence may be present seaward of the study region (e.g. at ODP Site 1073 on the Hudson Apron).

\subsection{Independent measurements of eustatic change during the late Miocene-Pleistocene}

The distinct stacking patterns of the middle Miocene through Pleistocene strata of the New Jersey margin are present in globally distributed continental margins that have sufficient sediment supply and relatively constant tectonic subsidence (Bartek et al., 1991). These margins all show a major progradational episode during the middle Miocene, aggradation during the late Miocene, a lowermost Pliocene flooding, Pliocene-lower Pleistocene aggradation, and high-frequency Pleistocene cyclicity.

Kominz (1984) estimated the eustatic sea level change that resulted from changing mid-ocean ridge volume. She predicted an eustatic fall during the middle Miocene and an eustatic rise from the late Miocene to the present (Fig. 13). Lincoln and Schlanger (1991) interpreted small amplitude eustatic changes in the late Miocene from the lack of exposure surfaces in carbonate atolls. During the early to middle Pliocene ( 5.3-3.0 Ma), minor Antarctic deglaciation and global warming is inferred (Hodell and Venz, 1992; Shackleton et al., 1995). During this period, the Enewetak Atoll records a relative sea-level highpoint from which an eustatic highstand is inferred (Lincoln and Schlanger, 1991; Wardlaw and Quinn, 1991).

We interpret the transgressive components of the late Miocene-Pliocene sequence to record eustatic stillstand or rise (as compared to the eustatic fall of the middle Miocene). Within this 5 m.y. period, higher frequency (m.y.) eustatic oscillations may have formed the cycles recorded in units $A_{1}$ and $A_{2}$.

The progradation and erosion recorded at the top of the late Miocene-Pliocene sequence (unit $\mathrm{B}_{2}$ ) resulted from eustatic fall driven by the growth of bipolar ice sheets from $\sim 3.0 \mathrm{Ma}$ to $\sim 1.3 \mathrm{Ma}$ (Raymo, 1994). The Enewetak Atoll sea-level record of Wardlaw and Quinn (1991) also records a sea-level fall from 3.0 Ma through the remaining Pliocene, with disconformities at $\sim 2.3 \mathrm{Ma}$ and $1.3 \mathrm{Ma}$.

The role of eustasy on the Pleistocene sequence is less clear. Prior to $0.9 \mathrm{Ma}$, sea-level change inferred from the $\delta^{18} \mathrm{O}$ record was driven by climate changes dominated by a $41 \mathrm{k} . \mathrm{y}$. period whereas after $0.9 \mathrm{Ma}$ it has been driven by a 100 k.y. period (Hodell and Venz, 1992; Raymo, 1997; Clark and Pollard, 1998). The Pleistocene sequence spans $\sim 1.5$ m.y. during a time dominated by these high-frequency large amplitude oscillations.

\subsection{Correlation with the North Atlantic coastal plain and the Great Bahama Bank}

We correlate our sequences with those present in the North Atlantic coastal plain (Fig. 13E). At the Cape May borehole (New Jersey), de Verteuil (1997) determined that the Cohansey Formation was composed of six sequences of middle and late Miocene age (Ch1-Ch6). He correlated these sequences with the SE8-SE11 sequences present in the Salisbury Embayment (Maryland and Virginia) (Fig. 13). As interpreted by de Verteuil (1997), sequences Ch5 and Ch6 of Cape May correlate with SE 11 of the Salisbury embayment, and with the post Saint Mary sequence (pSM) of Kidwell (1997). Kidwell (1997) described the pSM interval as a transgressive incised-valley deposit that is distinct from the underlying St. Marys Formation (which records progradational cycles). These sequences (Ch5 Ch6, SE11 and pSM) are coeval with the base of the late Miocene-Pliocene sequence of this study (Fig. 13E and F).

Strata overlying the Cohansey and post Saint Mary Formations are generally described as lying unconformably on these strata and of indeterminate (Pleistocene to recent) age (e.g. Kidwell, 1997). An exception is the work of Krantz (1991) who correlated Pliocene and Pleistocene strata across the middle Atlantic coastal plain (Fig. 13E). Generally, these sequences deepen upward, are bounded above and below by erosional unconformities, and are interpreted 
to record highstands in sea-level (Krantz, 1991). The Yorktown Formation and its overlying unconformity correlate with the upper part of the late MiocenePliocene sequence and pp4(s), respectively. The Windsor Formation correlates with the Pleistocene sequence of this study.

Miocene and younger carbonate strata were drilled on the western flank of the Great Bahama Bank during ODP Leg 166. Eberli et al. (1997) traced 17 seismically mapped sequence boundaries imaged in the shelfal areas to the slope and basinal areas of ODP Leg 166 (Fig. 13).

Eberli et al. (1997) reported on two core borings drilled updip from the ODP Leg 166 sites. These locations (Clino and Unda) are most analogous to the Site 1071 and Site 1072 boreholes because they penetrate Miocene through Pleistocene strata at relatively shallow paleo-water depths. Five seismically defined sequences were defined in the Miocene through Pleistocene strata (h through $\mathrm{d}$ ), each of which has underlying sequence boundaries (H through D) (Fig. 13D). The base of sequence $\mathrm{h}$ records backstepping of the margin. Sequence $g$ records the development of reefs on the continental slope. The base of sequence $f$ records rapid and significant backstepping of the margin. Eberli (personal communication) interprets this stratigraphic succession resulted from an initial eustatic rise at approximately $8.9 \mathrm{Ma}$ that remained relatively high until the very late Miocene; at approximately 5.9 Ma eustatic sea-level dropped and a reef was established on the slope. During the early Pliocene, sea level rose again at a fast rate causing a second backstep of the margin.

The observations and interpretations of Eberli et al. (1997) and Eberli (personal communication) are consistent with this study. The deepening recorded by Eberli et al.'s (1997) sequence h is coeval with the deepening recorded at the base of the late Miocene-Pliocene sequence (Fig. 13). The shallowing recorded by their sequence $\mathrm{g}$ is approximately coincident with the formation of units $A_{1}$ and $A_{2}$ of this study. The deepening recorded at the base of their sequence $\mathrm{f}$ is coincident with the deepening recorded by unit $\mathrm{B}_{1}$ of this study (given the very approximate age control available (Table 1)). Eberli et al. (1997) also interpreted large scale sea-level fall at the end of the Pliocene due to development of northern hemisphere glaciers and worldwide drop in sea level. In the Pleistocene, numerous subaerial exposure horizons in both Unda and Clino are interpreted to record frequent middle and late Pleistocene highstand flooding events.

\section{Conclusions}

Analysis of 2-D seismic, wireline log, and core data at ODP Leg 174A Sites 1071 and 1072 on the outer continental shelf of New Jersey reveals two major depositional sequences of late Miocene-Pliocene and Pleistocene age, respectively. These sequences have very different architectures than the underlying middle Miocene sequences. The late MiocenePliocene sequence is characterized by a thick $(\sim 100 \mathrm{~m})$, deepening-upward succession landward of the clinoform rollover and a shoaling-upward succession deposited during later regression seaward of the clinoform rollover. The Pleistocene sequence deepens abruptly near its base, shoals-upward, and then deepens again before it is truncated by its overlying unconformity. There is no onlap onto clinoforms (no lowstand wedge) in either sequence.

We attribute the differences between the late Miocene-Pliocene and middle Miocene sequences to result from different long term accommodation histories. The transgressive component of the late Miocene-Pliocene sequence was formed by highfrequency eustatic cycles (1-2 m.y.) superimposed on a longer-term eustatic rise ( $\sim 5 \mathrm{~m} . \mathrm{y}$.). In contrast, the underlying middle Miocene sequences were formed by high-frequency eustatic changes superimposed on a longer-term eustatic fall.

\section{Acknowledgements}

This research would not have been possible without the tireless efforts of both staff and scientists present on the Joides Resolution during ODP Leg 174A. J. Metzger received support from an Anadarko Petroleum Corporation Fellowship. This project was funded through Ocean Drilling Program Grant 418925-BA206 and Petroleum Research Fund Grant 33276-AC8. We also thank A. Shaw (Penn State University), and the technical staff at both the Institute of Geophysics (The University of Texas, Austin) and at Lamont Doherty Earth Observatory for help in 
loading the seismic data to the workstation. The Minerals Management Service donated log data. Seisworks 2D software, donated by the Landmark Graphics Company, was used in this study. Paradigm's Geolog6 was used for log interpretation. M. Kominz, K. Miller, J. Wright, and G. Eberli assisted the comparison of ODP Leg 174A results with other measurements of sea level change. R. Steel and F. Surlyk reviewed the manuscript.

\section{References}

Abreu, V.T., Anderson, J.B., 1998. Glacial eustasy during the Cenozoic: sequence stratigraphic implications. Am. Assoc. Pet. Geol. Bull. 82, 1385-1400.

Austin, J.A. Jr., Christie-Blick, N., Malone, M.J. (Eds.), 1998. Proc. ODP, Init. Repts., 174A. College Station, TX (Ocean Drilling Program), 324pp.

Bartek, L.R., Vail, P.R., Anderson, J.B., Emmet, P.A., Wu, S., 1991. Effect of Cenozoic ice sheet fluctuations in Antarctica on the stratigraphic signature of the Neogene. J. Geophys. Res. 96, 6753-6778.

Berggren, W.A., Kent, D.V., Swisher, C.C., Aubry, M.P., 1995. A revised Cenozoic geochronology and chronostratigraphy. Geochronology, time scales and global stratigraphic correlations: a unified temporal framework for a historical geology, Berggren, W.A., Kent, D.V., Swisher Jr., C.C., Aubry, M.P. (Eds.). Soc. Econ. Paleontol. Mineral. Spl. Publ. 54, 129-212.

Christie-Blick, N., Mountain, G.S., Miller, K.G., 1990. Seismic stratigraphic record of sea-level change, Sea-Level Change, Natl. Acad. Press, Washington, DC (pp. 116-140).

Clark, P.U., Pollard, D., 1998. Origin of the middle Pleistocene transition by ice sheet erosion of regolith. Paleoceanography 13, 1-9.

Eberli, G.P., Swart, P.K., Malone, M.J., Shipboard Scientific party, 1997. Leg synthesis: Sea-level changes and fluid flow on the Great Bahama Bank slope, in Eberli, G.P., Swart, P.K., Malone, M.J., et al. (Eds.), Proc. ODP, Init. Repts., 166: College Station, TX. (Ocean Drilling Program), pp. 13-22.

Eberli, G.P., Swart, P.K., McNeill, D.F., Kenter, J.A.M., Anselmetti, F.S., Melim, L.A., Ginsburg, R.N., 1997. A synopsis of the Bahamas Drilling Project: results from two deep core borings drilled on the Great Bahama Bank. In: Eberli, G.P., Swart, P.K., Malone, M., et al. (Eds.), Proc. ODP, Init. Repts., 166: College Station, TX (Ocean Drilling Program), pp. 23-42.

Flower, B.P., Kennett, J.P., 1994. The middle Miocene climatic transition: East Antarctic ice sheet development, deep ocean circulation and global carbon cycling. Palaeogeogr. Palaeoclimatol. Palaeoecol. 108, 537-555.

Fulthorpe, C.S., Austin Jr., J.A., 1998. Anatomy of rapid margin progradation: three dimensional geometries of Miocene clinoforms, New Jersey margin. Am. Assoc. Pet. Geol. Bull. 82, 251-273.

Fulthorpe, C.S., Mountain, G.S., Miller, K.G., 1996. Mapping
Neogene depositional geometries, New Jersey Continental Slope, Leg 150 drilling area. In: Mountain, G.S., Miller, K.G., Blum, P., Poag, C.W., Twichell, D.C. (Eds.), Proc. ODP, Sci. Results, 150. College Station, TX (Ocean Drilling Program) pp. 269-281.

Fulthorpe, C.S., Austin Jr., J.A., Mountain, G.S., 1999. Buried fluvial channels off New Jersey: Did sea-level lowstands expose the entire shelf during the Miocene? Geology 27 (3), 203-206.

Greenlee, S.M., Moore, T.C., 1988. Recognition and interpretation of depositional sequences and calculation of sea-level changes from stratigraphic data-offshore New Jersey and Alabama Tertiary. Sea-level changes: an integrated approach, Wilgus, C.K., Hastings, B.S., Kendall, C.G.St.C., Posamentier, H.W., Ross, C.A., Van Wagoner, J.C. (Eds.). Soc. Econ. Paleontol. Mineral. Spl. Publ. 42, 329-353.

Greenlee, S.M., Schroeder, F.W., Vail, P.R., 1988. Seismic stratigraphic and geohistory analysis of Tertiary strata from the continental shelf off New Jersey-calculation of eustatic fluctuations from stratigraphic data. In: Sheridan, R.E., Grow, J.A. (Eds.), The Atlantic Continental Margin of the United States. Geol. Soc. Am. Boulder, Colo., pp. 437-444.

Greenlee, S.M., Devlin, W.J., Miller, K.G., Mountain, G.S., Flemings, P.B., 1992. Integrated sequence stratigraphy of Neogene deposits, New Jersey continental shelf and slope: Comparison with Exxon model. Geol. Soc. Am. Bull. 104, 1403-1411.

Grow, J.A., Sheridan, R.E., 1988. US Atlantic continental margin; a typical Atlantic-type or passive continental margin. In: Sheridan, R.E., Grow, J.A. (Eds.), The Atlantic Continental Margin of the United States. Geol. Soc. Am. Boulder, Colo., pp. 1-7.

Haq, B.U., Hardenbol, J., Vail, P.R., 1987. Chronology of fluctuating sea levels since the Triassic. Science 235, 1156-1167.

Helland-Hansen, W., Gjelberg, J.G., 1994. Conceptual basis and variability in sequence stratigraphy: a different perspective. Sediment. Geol. 92, 31-52.

van Hinte, J.A., Wise Jr., S.W. (Eds.), 1987. Init. Repts. DSDP, 93, Washington, US Government Printing Office.

Hodell, D.A., Venz, K., 1992. Toward a high-resolution stable isotope record of the southern ocean during the PliocenePleistocene (4.8-0.8 Ma). The Antarctic paleoenvironment: a perspective on global change, Kennett, J.P., Warnke, D.A. (Eds.). Antarct. Res. Ser. 56, 265-310.

Jervey, M.T., 1988. Quantitative geological modeling of siliciclastic rock sequences and their seismic expression. Sea-level changes: an integrated approach, Wilgus, C.K., Hastings, B.S., Kendall, C.G.St.C., Posamentier, H.W., Ross, C.A, Van Wagoner, J.C. (Eds.). Soc. Econ. Paleontol. Mineral. Spl. Publ. 42, 47-69.

Kidwell, S.M., 1997. Anatomy of extremely thin marine sequences landward of a passive-margin hinge zone: Neogene Calvert cliffs succession, Maryland, USA. J. Sedimentary Res. 67, 322-340.

Kominz, M.A., 1984. Ocean Ridge volumes and sea-level changean error analysis. In: Schlee, J.S. (Ed.), Inter-regional unconformities and hydrocarbon accumulation, AAPG Memoir 36, pp. 109-127. 
Krantz, D.E., 1991. A chronology of Pliocene sea-level fluctuations. Quat. Sci. Rev. 10, 163-174.

Lincoln, J.M., Schlanger, S.O., 1991. Atoll stratigraphy as a record of sea level change: problems and prospects. J. Geophys. Res. 96, 6727-6752.

Miller, K.G., Snyder, S.W. (Eds.), 1997. Proc. ODP, Sci. Results, 150X. College Station, TX (Ocean Drilling Program), 388pp.

Miller, K.G., Fairbanks, R.G., Mountain, G.S., 1987. Tertiary oxygen isotope synthesis, sea level history, and continental margin erosion. Paleoceanography 2, 1-19.

Miller, K.G., Mountain, G.S., Browning, J.V., Kominz, M., Sugarman, P.J., Christie-Blick, N., Katz, M.E., Wright, J.D., 1998a. Cenozoic global sea level, sequences, and the New Jersey transect: results from coastal plain and continental slope drilling. Rev. Geophys. 36, 569-601.

Miller, K.G., Sugarman, P.J., Browning, J.V. (Eds.), 1998b. Proc. ODP, Init. Repts., 174AX. College Station, TX (Ocean Drilling Program), 43pp.

Mountain, G.S., Miller, K.G., Blum, P., Poag, C.W., Twichell, D.C. (Eds.), 1996. Proc. ODP, Sci. Results, 150. College Station, TX (Ocean Drilling Program), 493pp.

Mountain, G.S., Monteverde, D., Flemings, P.B., 1998. Sequence stratigraphy at the edge: core-log-seismic correlations of Pleistocene sediments on the outermost New Jersey Margin. AGU Abstr. Prog. F472.

Nummedal, D., Swift, D.J.P., 1987. Transgressive stratigraphy at sequence-bounding unconformities: some principles derived from Holocene and Cretaceous examples. Sea-level Fluctuation and Coastal Evolution, Nummedal, D., Pilkey, O.H., Howard, J.D. (Eds.). Soc. Econ. Paleontol. Mineral. Spl. Publ. 41, 241-259.

Poag, C.W., 1985. Depositional history and stratigraphic reference section for central Baltimore Canyon trough. In: Poag, C.W. (Ed.). Geologic Evolution of the United States Atlantic Margin, Van Nostrand Reinhold, New York, pp. 217-263.

Poag, C.W., Sevon, W.D., 1989. A record of Appalachian denudation in postrift Mesozoic and Cenozoic sedimentary deposits of the US middle Atlantic margin. Geomorphology 2, 119-157.

Poag, C.W., Watts, A.B. (Eds.), 1987. Init. Repts. DSDP, 95 Washington, US Government Printing Office.

Posamentier, H.W., Allen, G.P., 1993. Variability of the sequence stratigraphic model: effects of local basin factors. Sediment. Geol. 86, 91-109.

Poulsen, C.J., Flemings, P.B., Robinson, R.A.J., Metzger, J.M., 1998. Three-dimensional stratigraphic evolution of the Miocene Baltimore Canyon region: Implications for eustatic interpretations and the systems tract model. Geol. Soc. Am. Bull. 110, 1105-1122.
Raymo, M.E., 1994. The initiation of northern hemisphere glaciation. Annu. Rev. Earth Planet. Sci. 22, 353-383.

Raymo, M.E., 1997. The timing of major climatic terminations. Paleoceanography 12, 577-585.

Reynolds, D.J., Steckler, M.S., Coakley, B.J., 1991. The role of sediment load in sequence stratigraphy: the influence of flexural isostasy and compaction. J. Geophys. Res. 96, 6931-6949.

Rine, J.M., Tillman, R.W., Stubblefield, W.L., Swift, D.J.P., 1986. Lithostratigraphy of Holocene sand ridges from the nearshore and middle continental shelf of New Jersey. In: Moslow, T.F., Rhodes, E.G. (Eds.), Modern and Ancient Shelf Clastics. Soc. Econ. Paleontol. Mineral., Core Workshop, vol. 9, pp. 1-72.

Scholle, P.A. (Ed.), 1977. Geological studies on the COST No. B-2 well, US mid-Atlantic outer continental shelf area, Geol. Surv. Circ. (US) 750 .

Shackleton, N.J., Hall, M.A., Pate, D., 1995. Pliocene stable isotope stratigraphy of Site 846. In: Pisias, N.G., Mater, L.A., Janecek, T.R., Palmer-Julson, A., van Andel, T.H. (Eds.), Proc. ODP, Sci. Results, 138. College Station, TX (Ocean Drilling Program), pp. 337-353.

Smith, M.A., Amato, R.V., Furbush, M.A., Pert, D.M., Nelson, M.E., Hendrix, J.S., Tamm, L.C., Wood, G. Jr., Shaw, D.R., 1977. Geological and Operational Summary, COST B-2 Well, Baltimore Canyon Trough Area, Mid-Atlantic OCS, Open File Report, pp. 76-174.

Steckler, M.S., Watts, A.B., 1982. Subsidence history and tectonic evolution of Atlantic-type Continental Margins. Dynamics of Passive Margins, Scrutton, R.A. (Ed.). Am. Geophys. Union Geodyn. Ser. 6, 184-196.

Steckler, M.S., Reynolds, D.J., Coakley, B.J., Swift, B.A., Jarrod, R., 1993. Modeling passive margin sequence stratigraphy. Sequence Stratigraphy and Facies Associations, Posamentier, H.E., Summerhayes, H.E., Haq, B.U., Allen, G.P. (Eds.). Int. Assoc. Sedimentol. Spl. Publ. 8, 19-41.

de Verteuil, L., 1997. Palynological delineation and regional correlation of lower through upper Miocene sequences in the Cape May and Atlantic City boreholes, New Jersey Coastal Plain. In: Miller, K.G., Snyder, S.W. (Eds.), Proc. ODP, Scientific Results, 150X. College Station, TX. (Ocean Drilling Program), pp. 129-145.

Walker, R.G., 1995. Sedimentary and tectonic origin of a transgressive surface of erosion: Viking Formation, Alberta. Can. J. Sediment. Res. 65, 209-221.

Walker, R.G., Eyles, C.H., 1991. Topography and significance of a basinwide sequence-bounding erosion surface in the Cretaceous Cardium Formation, Alberta, Canada. J. Sediment. Petrol. 61, 473-496.

Wardlaw, B.R., Quinn, T.M., 1991. The record of Pliocene sea-level change at the Enewetak atoll. Quat. Sci. Rev. 10, 247-258. 